NBER WORKING PAPER SERIES

WHAT HAVE TWO DECADES OF BRITISH ECONOMIC REFORM DELIVERED?

\author{
David Card \\ Richard B. Freeman \\ Working Paper 8801 \\ http://www.nber.org/papers/w8801 \\ NATIONAL BUREAU OF ECONOMIC RESEARCH \\ 1050 Massachusetts Avenue \\ Cambridge, MA 02138 \\ February 2002
}

Prepared for the forthcoming volume Seeking a Premier League Economy, edited by Richard Blundell, David Card, and Richard B. Freeman. We are grateful to Till von Wachter and Rishi Madlani for research assistance, and to Mary O'Mahoney for generously sharing her data. The views expressed herein are those of the authors and not necessarily those of the National Bureau of Economic Research.

(C) 2002 by David Card and Richard B. Freeman. All rights reserved. Short sections of text, not to exceed two paragraphs, may be quoted without explicit permission provided that full credit, including (C) notice, is given to the source. 
What Have Two Decades of British Economic Reform Delivered?

David Card and Richard B. Freeman

NBER Working Paper No. 8801

February 2002

\begin{abstract}
Beginning in 1979 with the newly elected Thatcher Government and continuing under successive Conservative and Labour Governments, the United Kingdom has embarked on a two-decade-long experiment in economic reform. We present evidence that the reform process has succeeded in making the UK more market-friendly than its European competitors. In fact, by the 1990s Britain ranked near the top of the league tables for freedom of markets, in some cases even ahead of the United States. To evaluate the effects of these reforms we compare trends in macroeconomic outcomes in the UK relative to the US, Germany, and France. During the 1980s and 1990s Britain halted the relative declines in GDP per capita and labour productivity that had characterized earlier decades, and partially closed the gap in income per capita with France and Germany. These gains were mainly attributable to relative rises in employment and hours. Unlike its EU competitors, Britain was able to achieve high employment-population rates with rising real wages for workers. The case that the change in economic performance can be credited to market-oriented reforms is harder to prove. Nevertheless, based on our own macro-level analyses, and micro-level evidence from several companion studies, we conclude that economic reforms contributed to halting the nearly century-long trend in relative economic decline of the UK relative to its historic competitors, Germany and France.
\end{abstract}

David Card

Department of Economics

University of California, Berkeley

Berkeley, CA 94720-3880

and NBER

card@econ.berkeley.edu
Richard B. Freeman

NBER

1050 Massachusetts Avenue

Cambridge, MA 02138

freeman@nber.org 


\section{What Have Two Decades of British Economic Reform Delivered?}

For much of the $19^{\text {th }}$ and $20^{\text {th }}$ centuries Britain, which pioneered the Industrial Revolution, had a disappointing growth record, falling markedly from the top ranks in the league economic tables. In 1979, the UK was 12 th in per capita GDP among advanced OECD countries, well below Germany, France, and other EU economies. ${ }^{1}$ In response to this weak economic performance, recent UK governments have adopted policies designed to move the economy back to "premiere league" status. Beginning with Mrs. Thatcher and continuing under John Major and Tony Blair, these reforms have sought to increase the efficacy of labour and product markets and limit government and institutional involvement in economic decision-making.

The move toward more markets and less government is not unique to the UK. Many other advanced economies also responded to the economic challenges of the 1980s and 1990s by granting markets more leeway in the allocation of resources and the setting of prices. All the major economies eliminated restrictions on the flow of capital by the early 1980s. Most privatized state-run industries in the 1980s and 1990s. All lowered marginal tax rates for high-income earners. Most also made labour contracts more flexible and moved from national wage setting to more localized collective agreements in the 1990s. For its part, the EU Commission pushed competition policies and the reduction of subsidies to declining industries while seeking a uniform social charter to regulate labour market outcomes. Outside the EU, the other English-speaking economies - the US, Canada, Australia, and New Zealand moved toward less state and institutional intervention in the economy.

Have two decades of economic reform significantly shifted the market orientation of the UK economy relative to other advanced OECD economies, or has the UK only kept pace with its peers? What have the reforms done for aggregate economic output and the average income of citizens? Have the reforms improved the position of the UK in the economic league tables?

${ }^{1}$ This refers to GDP per capita in purchasing power parity units, as reported in our table 8 , which includes 13 OECD countries. The precise position of the UK varies with the number of countries included in the analysis and particular purchasing parity adjustment used. 
This paper examines these questions. Section 1 compares the market-orientation of the UK relative to other advanced economies using a diverse set of market indicators. We find that the post- 1980 reforms have made the UK more market-friendly than its EU competitors, and that in the 1990 s the UK ranked higher on some measures of freedom of markets than the US. Section 2 contrasts macro-economic outcomes. We show that during the 1980s and 1990s the UK arrested the relative declines in GDP per capita and labour productivity that had characterized earlier decades, and partially closed the gap in per capita income with France and Germany through relative gains in employment and hours. While the UK did not experience an American-style "New Economy" boom, it combined high employment-population rates with rising real wages for workers: an achievement that the US was unable to match until the late 1990s. Section 3 examines the link between the reforms and outcomes. Since there is no ready counterfactual against which to compare the observed UK performance, our analysis is more judgmental. Based on macro-level analyses and the micro-level evidence available from several companion studies, how ever, we conclude that economic reforms contributed to halting the nearly century-long trend in relative economic decline of the UK relative to its historic competitors, Germany and France.

\section{The Market-Friendliness of the UK and other Advanced Economies}

"They used, when I first came in, to talk about us in terms of the British disease. Now they talk about us and say, 'Look, Britain has got the cure. Come to Britain to see how Britain has done it' That is an enormous turn-around." Margaret Thatcher, Financial Times, 15 February, 1988

"Government should have a role that is enabling: supporting small businesses, encouraging technological advance; investing in science; above all, promoting competition and removing the barriers to business growth... I call it a Third Way ... Supporting wealth creation. Tackling vested interests. Using market mechanisms." Tony Blair, speech at World Economic Forum, Davos 18 January 2000

For the past two decades British economic reforms have been motivated by a desire to increase the reliance on market forces and reduce the role of the state in the determination of prices and the allocation of resources. Mrs. Thatcher's Conservative government privatized industries and council housing, enacted laws to weaken trade unions, created financial incentives for workers to choose private 
pensions, and reduced the benefits available to unemployed workers, all the while preserving national health and other features of the welfare state. The Major government pursued a similar agenda, abolishing the Wages Councils and privatizing many of the remaining state-owned enterprises. Even after the defeat of the Conservatives, Tony Blair's New Labour government continued to introduce market-enhancing reforms. It created tax breaks for employee share ownership programs, opposed EU directives that were interpreted by private employers as anti-business, and enhanced the work incentives of the income support system. In the realm of monetary policy, Labour went beyond the Tories by shifting interest-rate-setting authority from the Treasury to an independent Monetary Policy committee. While there are some exceptions - the Thatcher campaign to centralize the public sector and limit the authority of local government, and the Blair efforts to ease the formation of unions and introduce a national minimum wage - the main thrust of UK policy reforms has been to reduce the economic role of the state and enhance the role of markets. ${ }^{2}$

For purposes of analysing the potential effect of these reforms on the economic performance of the UK relative to other advanced countries, it is important to determine whether these reforms were larger, smaller, or similar to those in other advanced countries. This in turn requires measures of the institutional and policy stance of advanced countries. In the absence of a single GDP-style measure of the free market stance of economies, we examine a variety of indicators that rate countries by the way different markets determine outcomes. Some of these indicators are based on objective data while others are based on the assessments of expert analysts or surveys of managers. Some of the measures are produced by think tanks with conservative ideological bents, such as the "economic freedom" indices of the Fraser Institute and the Heritage Foundation. These indices stress particular measures of economic freedom, such as low taxes, which fit a more conservative agenda, while ignoring social inclusion factors

\footnotetext{
${ }^{2}$ Since local governments must "compete" for residents and businesses (in the Tiebout sense), many economists believe that market forces exert greater discipline on the local public sector than on the central government. We therefore classify reforms which decentralize political decision-making as promarket, and those that centralize authority as anti-market.
} 
such as spending on education. Another broad set of measures are the indexes of "competitiveness" produced by the World Economic Forum, most recently in conjunction with the Harvard Center for International Development. These indices mix the stance of policy, institutions, and specific outcomes, and give higher scores to economically successful social democratic regimes than the freedom indices. Finally, the OECD and some independent scholars have produced indices of regulations and procedures in particular markets, such as labor markets, product markets, and capital markets.

All of these measures of the market friendliness of institutions have shortcomings. Some are formed by weighting linear sums of sub-indices, with the weights determined subjectively, and with some potential measures excluded. Some are scaled in ways that have little basis in theory or other empirical work. Some treat all regulations and administrative decrees as if they were rigidly enforced, when in fact the degree of enforcement of regulations that limit markets varies across countries. All the measures ignore potential complementarities or substitutions among institutions.

Competitiveness indices have other problems. The groups who provide these measures have changed their modes of calculating competitiveness over time, so that their indices do not reflect the same underlying data over time. In 2001, for example, the Fraser Institute revised its historical indices, producing generally modest adjustments as they accumulated additional data (see www.fraserinstitute.ca) The W orld Economic Forum-Harvard Center for International Development 2000 Competitiveness Report reported two different indices, one for "current competitiveness" and one for "growth competitiveness", reflecting the different weights placed on the same data for different purposes. Finally, the measures for individual markets can be criticized for focusing on some features of markets and regulatory mechanisms but not on others. For instance, measures of labour market performance concentrate on the extent of centralization of bargaining and employment protection legislation, but not on the potential for court suits over discrimination or insurance of pension moneys. Comparisons of the market-friendliness of product markets ignore difference in bankruptcy laws, which can greatly affect business formation and dissolution. While the sub-indices necessarily cover only parts of economies, 
they provide checks on the more aggregate measures. If an aggregate index rates an economy as marketfriendly while it has highly restrictive labour contracts or a highly regulated product market, then we will know that something is amiss. These measures also allow analysts to relate policies or institutions to the specific outcomes they are designed to affect, rather than to measures like GDP per capita, which depend on a wider set of factors.

\section{Where the UK Fits in Economic Freedom and Competitiveness}

Differences and shortcomings among the indices notwithstanding, the principal indicators of the market stance of economies show that the policy reforms of the 1980s and 1990s made the UK one of the most market friendly economies in the world. The high rank of the UK in market friendliness at the turn of the $21^{\text {st }}$ Century reflects more rapid market-oriented reforms in the UK than in most other advanced economies, rather than a general increase in regulation in other countries.

\section{a. Measures of Economic Freedom}

The indices of economic freedom produced by the Fraser Institute and the Heritage Foundation value key features of capitalist economies: private property rights, freedom to operate a business, and freedom of capital and labor markets. Both include measures of free trade, which reflect international policies, while neither includes measures of immigration policies. Each treats cursorily the labour market institutions that have drawn continuing policy attention in the wake of the divergence of unemployment and employment-population rates between the US and the EU in the 1980s and 1990s. Morever, the indices differ in their emphasis on particular dimensions of "freedom" (Hanke and Walters, 1997). The Fraser Institute Index rates countries with military conscription as having less economic freedom, and gives countries with higher top marginal tax rates and government transfers and subsidies lower scores. ${ }^{3}$

\footnotetext{
${ }^{3}$ Comparing the higher ranking that the Heritage/WSJ gives to Israel, which has conscription, than the Fraser Institute, Alvin Rabushka (2000) argued that the "Fraser Institute index is far superior to that of the Heritage/W SJ. It is based on far more extensive research, deliberation, and testing by far more qualified and distinguished scholars".
} 
The Heritage Foundation/W all Street Journal index penalizes higher corporate and value-added taxes. Reflecting the view that even a democratically chosen state sector is inimical to economic freedom, the Fraser and Heritage indices rate the size of government as important negative indicators of freedom. Both measures penalize high inflation, although this is an outcome of economic policy and market function, rather than an indicator of market orientation.

A third aggregate index of economic freedom was created by Freedom House. This index differs somewhat from the other two - for example, it ignores the level of taxation but counts freedom of association in the labour market. The index was produced only one, and so we leave it out of our analysis. Nevertheless, it is sufficiently highly correlated with the other two indicators that we do no harm to the analysis by excluding it.

While the Fraser and Heritage measures lead to somewhat different rankings of the market stance of particular countries, the high correlation between them shows that they are measuring essentially the same phenomenon. For all of the countries covered, including the less developed countries, Hanke and Walters (1997) report a rank-order correlation between the two indexes of 0.85 in 1995-96. For advanced OECD countries, we obtain a rank correlation of 0.83 between the Fraser and Heritage/W SJ measures. Most importantly, both indices give a relatively high rank to the UK in the 1990s. The Heritage/WSJ index ranks the UK third in 1996 among advanced OECD countries in market friendliness (after the US and New Zealand, tied with the Netherlands) and 5th in 2001 (after Ireland, New Zealand, US, and Lux emburg). ${ }^{4}$ According to the Fraser Institute index, the UK was tied for second with the US in 1995 among the advanced OECD countries (after New Zealand), while in 1999 it ranked 2nd after New Zealand and just ahead of the US. ${ }^{5}$

${ }^{4}$ In the Freedom House ranking in 1996, the UK was tied with the US and 4 other countries for the top rank.

${ }^{5}$ We exclude Singapore, Hong Kong and Bahrein from the rankings since they are not advanced OECD countries, but in some years they score higher than the UK 


\section{a.1 Fraser Institute Index}

Because the Fraser Institute Index (FII) is available from 1970 to the present, while the Heritage index covers a shorter period, we use the FII to measure the change in the UK's position over time. The FII measures the degree of economic freedom on a scale from 1 to 100 , with higher values reflect more freedom in market transactions.

Table 1 reports the FII for the UK and other major OECD countries every five years from 1970 to 1995 and for 1999. The levels and trends in the value of the index for various countries accord well with informal observations on the level and change in policy stances toward markets. For example, most analysts place the US and other English-speaking countries at the market-friendly end of the spectrum, and Nordic countries and other social democratic EU countries at the other end. The FII orders the countries in the same manner. Still, the index has potential errors. It does not deal with the implementation or enforcement of regulations that limit markets, so countries like Italy with a sizeable underground economy are arguably given too low a score. It also ignores the use of the judicial system to regulate market transactions, which may lead to an overstatement of the market freedoms in the US.

From 1970 to 1975 the index shows a decline in economic freedom in most countries (though not the US) when governments struggled to control inflationary pressures. This is odd since the US introduced wage and price controls in this period while many other countries relied on collective bargaining agreem ents to contain wage pressures. ${ }^{6}$ From 1980 to 1999 there was a general trend toward increased market freedoms.

Focusing on the UK, the FII tells a clear story about trends in the market friendliness. In the 1970s, before the Thatcher reforms, the UK scored relatively low among advanced countries in the economic freedom league table. In 1970 and 1975, when the UK had exchange controls, it ranked $17^{\text {th }}$ and $16^{\text {th }}$. By 1980 , after the elimination of controls, the UK had risen to $13^{\text {th }}$ position. Over the

${ }^{6}$ Canada also adopted wage and price controls in the period between 1975 and 1980, and yet the FII shows a rise in economic freedom. 
following two decades it rose sharply in the rankings, so that by 1999 , the UK stood second behind only New Zealand among the advanced OECD countries. Measured by the change in FII points, the UK was the third most reformed economy between 1980 and 1999, after New Zealand and Portugal. Thus, in an epoch of increasing market-friendly economic reforms, the UK reformed more than most other advanced countries.

The Fraser Institute index contains seven components, four of which - the total size of government expenditures, monetary policy and price stability, regulation of international exchange and freedom to trade with foreigners, and freedom to use alternative currencies - fall outside the purview of the micro-domestic policies which are our primary focus. Accordingly, in Table 2 we show the three components of the FII that more closely reflect domestic market freedoms: the structure of economy and use of markets, legal structure and property rights, and freedom of exchange in capital and financial markets. $^{7}$ As a crude summary, we also report the unweighted average of these components. They show that the UK ranked in the middle of the pack in 1980 but near the top by 1999 , considerably ahead of most of its EU competitors.

\section{b. World Economic Forum/Harvard Institute Competitiveness Scores}

Since 1980 the International Institute for Management Development (IMD) and the World Economic Forum (WEF) have developed jointly or separately a world competitiveness report of countries. From 1998 to 2000 the WEF collaborated with Harvard University's Center for International Development to give the Global Competitiveness Report (GCR) In contrast to the economic freedom indices, indices of competitiveness measure the "set of institutions and economic policies supportive of high rates of economic growth in the medium run." (GCR, 2000, p 14). The competitiveness scores are based on a mixture of quantitative economic measures and the responses of executives to questions about

${ }^{7}$ Freedom of exchange in capital and financial markets includes a subcategory for freedom of citizens to engage in capital transactions with foreigners, so this is not exclusively a measure of domestic market activities. Note that the vast majority of countries score 100 in the legal structure and property rights sub-index in 1997, while the remainder are in the 90+ range, except for Greece. 
the situation in their country. Most of the questions in the 2000 Report ask executives to rate "the extent to which" a country fits a particular statement on a scale from 1 to 4 ; earlier reports used a scale from 0 (not at all) to 100 (to a great extent). The response rate to the survey has varied in the range of $15 \%$ to $20 \%$, with non-respondents having similar characteristics to respondents.

Because the competitiveness scores are heavily weighted toward actual (or prospective) economic performance, the rankings of countries differ from rankings based on the market friendliness of their institutions. Some highly regulated countries such as Germany, Switzerland, and the Nordic countries, and others such as Japan that have performed better during various time periods than the market-friendly English-speaking countries receive higher competitiveness scores. For instance, in 1990 Japan, Switzerland, Germany, and Sweden scored higher on the world competitiveness index than less-regulated UK, Ireland, and Australia. Across all countries, however, Hanke and Walters (1997) report that competitiveness scores are highly correlated with the Fraser Institute and Heritage/WSJ indices of economic freedom, with rank-order correlation coefficients in the area of 0.85 .

Table 3 shows the competitiveness index rankings for advanced OECD countries in the 2000 Global Competitiveness Ranking and some of the sub-indices that go into the aggregate measures. Column 1 records ranks in the GCR's "growth competitiveness" index, which is designed to measure a country's standing in the factors likely to produce economic growth. Column 2 gives its rank in "current competitiveness", which is designed to measure factors that are likely to determine the level of economic activity. While the two indices rank some countries differently, most notably Germany (poor in growth competitiveness but good in current competitiveness), they give similar scores to the UK. By either measure, the UK ranks in upper third or so of advanced OECD countries. This is considerably above the position of the UK in GDP per capita tables, but falls well short of the top 3 rating that the UK received in the indices of economic freedom.

Why does the UK rate lower in competitiveness than in market freedoms? The lower ranking does not reflect differences in the ranking that the GCR and Fraser or Heritage foundations give to 
indicators of market freedoms. For example, column (3) shows that the UK is $2^{\text {nd }}$ in one GCR indicator that meshes well with the indexes of market freedom -- the time executives say that they spent dealing with government bureaucracies. Column (4) shows that the UK ranks $6^{\text {th }}$ in protection of property rights, which was one of the major factors in indices of economic freedom, ahead of the US, Germany, and France. The area where the UK does relatively poorly is in the provision of public services. This is illustrated in columns 5 and 6 of Table 3 . The UK scores $17^{\text {th }}$ in terms of overall infrastructure and $20^{\text {th }}$ in the quality of public schools. While economists are uncertain about the contribution of infrastructure to national output, and of the effect of school quality on productivity, both factors surely do affect economic performance. ${ }^{8}$

\section{c. Indices for Specific Markets: Product Markets}

To assess the extent and intrusiveness of regulations on business in 1988 the OECD sent a detailed questionnaire to member states asking about 1,300 different regulations concerning economywide and industry specific laws, regulations, and administration of laws. ${ }^{9}$ The responses to this questionnaire form the basis of the OECD regulatory data base, which is the most comprehensive and detailed body of information on product market regulations across countries. The data base measures administrative regulations but does not take account of differences in the use of the judicial system to regulate product markets. Since legal challenges to business operations are a greater threat in the US than in most other countries, indexes based on the IRDB arguably over-state the market-friendly orientation of the US economy. Only in the US do liability suits have the potential to bankrupt firms (as they have done

${ }^{8}$ The GCR gives the UK a mixed record in use of modern technology. The UK scores among the top 10 countries in terms of innovation but much lower in its ability to copy technological advances of other countries (World Economic Forum-HCID Economic Competitiveness 2000 Report). The Fraser Institute measures of protection of patent rights gives the UK a rank of 14 among 15 advanced countries (Fraser Institute, 2001, exhibit 4-3 A).

${ }^{9}$ The OECD supplemented the questionnaire with information from other sources, so that about 10 percent of the data comes from other sources. See Nicoletti, Scarpetta, and Boylaud (1999), and the overview in OECD (1999, chapter VII). 
in the cases of asbestos and breast implants, for example) and only in the US are class action and individual employment discrimination suits a major concern for business. ${ }^{10}$ In addition, the OECD regulatory data base does not really address the extent to which state regulators actually enforce regulations, which depends on the level of state funding for government agencies, the salaries paid to civil servants, and modes of compliance.

There are various ways to summarize the information on the 1,300 regulations in the OECD data base. In a companion report on the OECD report on the product market regulations, Nicoletti, Scarpetta, and Boylaud (2000) use a factor analysis procedure to derive aggregate measures of the burden of regulation in two key domains: inward oriented regulations, covering state control of industry, barriers to entrepreneurship, and regulations of domestic markets; and outward-oriented regulations, covering barriers to trade and investment. The scaling is such that higher scores mean a thicker and more intrusive set of regulations - and thus one nominally less friendly to market mechanisms. Different aggregations of the information in the database would give different measures to each country than Nicoletti, et al produce, but would presumably give a similar ordering of countries by the scope and depth of regulatory practices. We use the Nicoletti et al measures in this paper.

Table 4 records the product market regulatory scores for the OECD countries. In all of the inward oriented regulatory domains and in the overall score the UK is the least regulated economy. The US, Ireland, and Australia also show limited regulatory activity. At the other end of the spectrum, Italy, Norway and Greece have the most highly regulated product markets. In the outward-oriented domain the

${ }^{10}$ There are factors that work in the other direction as well. The regulatory scale gives the UK a lower score in barriers to entrepreneurship than the US, which is often cited as the ideal environment for aspiring entrepreneurs. The gap between the US and UK comes from two sub-indices: one that measures the "regulatory and administrative opacity" (attributed to the high number of administrative procedures and services involved in business startups) and another than measures barriers to competition. However, the IRDB may be misleading in this respect, because it fails to account for lenient US bankruptcy laws, which enable entrepreneurs who fail to start up again with less cost than in most other countries. And the OECD also failed to collect data on land-use regulations (OECD, 1999, footnote 8) which may be less restrictive in most parts of the US than the UK or other European countries. 
UK is tied with Ireland and Australia for the least regulated economy. Over all domains the UK is ranked as the least regulated of the OECD economies, with Ireland in second place and the US in third.

Nicoletti et al (2001) have used information from the OECD regulatory data base to create a measure of the coverage of regulations for each country from 1990 to 1996 that allows us to measure the changes in regulatory practices across countries. They find that all of the covered countries reduced regulations in the $1990 \mathrm{~s}$, but that the UK deregulated its markets to a greater extent than did the US, France, and Germany. In 1990 the UK was $7^{\text {th }}$ in freedom from regulation whereas in 1996 it was at the top of the table. This illustrates one of our major points: that the market reform stance of the UK continued post-Mrs. Thatcher.

That the UK developed a more market friendly regulatory regime in product markets than Germany and France fits well with general views of government involvement in these economies. But this does not necessarily mean that consumers are uniformly better off in Britain. The prices of some goods such as automobiles have long been higher in the UK than on the continent, reflecting the structure of private product markets. ${ }^{11}$ Still, the OECD has a clear message: the UK has gone from a regime of relatively medium regulation of business to a relatively deregulated regime in the period of economic reforms.

\section{d. Indices for Specific Markets: Labour Markets}

The labour market is arguably the most idiosyncratic market in modern capitalist economies. The extent and nature of unionization, employer associations, and regulations vary widely across countries, leading many analysts to try to explain differences in economic performance across countries in terms of differences in labour market institutions (for example Bruno and Sachs, 1985; Calmfors and Driffil, 1988; Freeman, 1998; OECD, 1999). To do this, these analysts have developed ratings of country wage-setting institutions and employment protection legislation, and have estimated union density and collective

\footnotetext{
${ }^{11}$ In April 2000, the UK Competition Commission issued a report finding that new car prices were about 10 percent higher in the UK than elsewhere in the EU - see Detroit News (2000).
} 
bargaining coverage.

Table 5 shows how different analysts ranked countries by their degree of centralization of wagesetting from the early 1980 s to the mid 1990s. In this table a high number means that the analyst regards the wage setting system as highly centralized while a low number means that the analyst regards the system as decentralized. Most analysts built their rankings from a limited number of "facts"(such as whether there is a central union negotiating body, whether there is one bargaining federation or many, etc.) analogous to the way the freedom or competitiveness indices are constructed. Several of the rankings give rise to ties between countries because the underlying facts are similar. Still, there is subjectivity in the building blocks chosen and, perhaps more importantly, in the weights that analysts accord them in aggregating to a single statistic. While analysts generally place the same countries at the top or bottom of the table in terms of market-based wage setting, there are some notable differences (for instance, in rating Japan or France). The UK is invariably among the countries that have more market based wage-setting. Over the period of reforms, the UK moved up the rankings as it shifted from a collectively bargained system of wage-setting to a largely market determined system. New Zealand followed a similar pattern.

But rankings can only tell us about changes in relative position. The final column in the table gives absolute changes in centralization of wage-setting as summarized by Elmeskov, Martin, and Scarpetta (1998). They code countries from 1 (decentralized wage setting) to 3 (coordinated or centralized) and specify periods of change. Eight countries change their wage-setting stance in the period they covered, with five moving towards less centralized institutions while the Netherlands, Ireland, and Italy moved in the opposite direction.

Quantitative data on the extent of unionism and collective bargaining coverage in the UK confirm this picture of movement toward more market-oriented wage-setting. In 1980 approximately $50 \%$ of UK workers were unionized and $70 \%$ were covered by collective bargaining (see Appendix Table 5). By contrast, twenty-odd years later, in 1997, 30\% of UK workers were unionized and only $44 \%$ were covered 
by collective bargaining. Relative to its major European competitors, the UK has a smaller fraction of nonunion workers who are covered by collective bargaining. France, which has a very low rate of unionization, has a very high rate of collective bargaining coverage because of laws that extend union contracts to nonunion workplaces. Germany lies somewhere between the UK and France. Over the 1980s and 1990s unionization and collective bargaining coverage remained roughly stable in Germany, compared to the declines in the UK. This reflects a more general pattern of divergence among OECD countries in the importance of unionism in the labour market.

In addition to having different institutions for wage-setting, advanced countries have different rules that regulate employment adjustments. EU countries like Spain, Portugal and Italy make it difficult to lay off workers with permanent contracts, while Germany and Belgium make it difficult to hire temporary labor. All continental EU countries have works councils and require management to consult with those councils about plant closings, which invariably delays closures and increases their cost. Employment protection policies effectively shift the property rights of a job from management to the incumbent worker. Several analysts have stressed the role of employment protection legislation (EPL) in constraining employer's flexibility and ultimately holding down the rate of employment growth (Lazear, 1990; Bertola, 1990; Grubb and Wells, 1993).

Comparisons of EPL across countries show that throughout the past two decades the UK was among the least restrictive countries on the rights of employers to alter employment at will. In the 1994 Jobs Study the OECD ranked the UK in fourth place in terms of reliance on market forces as opposed to EPL intervention in the labour market. Table 6 records ratings of the strictness of the EPL regulations in the late 1980 s and late 1990 s by the OECD. The scores given to the regulations are scaled so that low values (minimum of 0) imply little employment protection while high values (maximum of 6) imply considerable employment protection. The A measures in columns 1, 2, and 4 are based on data for regular contracts and temporary contracts. The B measures (in column 4, for the late 1990s only) add additional information on regulations covering collective dismissals. All the EPL measures show that the 
UK, US, and other English-speaking countries have the least restrictions on the rights of employers to alter employment at will. Over time, however, the difference between the UK and EU countries with more restrictive legislation declined over this period, as other EU countries weakened their regulation of regular contracts and eased the rules on temporary contracts. Because the UK had relatively weak regulations to begin with, employment protection legislation is an area where most other EU countries have moved their policies closer to those of the UK, though substantial differences in employment protection remain.

\section{e. Indices of Specific Market: Business Formation and Capital Markets}

To assess the ease of starting a new business, researchers in corporate finance have gathered data on regulations covering start-ups (Djankov, La Porta, Lopez-de-Silanes, Shleifer, 2000). Columns 1-3 of Table 7 summarize their analysis in terms of three broad measures of the ease of business formation: the estimated number of procedures needed to start a business, the estimated time to meet those requirements; and the estimated direct and indirect cost of meeting the requirem ents relative to GDP per capita. Djankav et al not the wide variation in these measures: "To meet government requirements for starting to operate a business in Austria, an entrepreneur must complete 12 procedures taking at least 154 days and pay US\$1 1,612 in government fees" (Djankov, et al, p. 1). This compares with 4 procedures that take 7 days at a cost of $\$ 2806$ in the US and even less in Canada (Djankov, et al, Table III). The UK is number 2 in terms of the estimated costs of forming a business relative to GDP, right behind New Zealand and ahead of the US.

To assess the protection given to investors to invest or loan money to firms, La Porta, Lopez-deSilanes, Shleifer, and Vishny (1999) have developed indices of the rights of investors and creditors in the various countries. Columns 4-7 of Table 7 present their summary measures of the assessment of law and order in the country (on a scale from 0 to 10 ), based on the International Country Risk Guide, and their indices of shareholder rights (scale of 0 to 4 ) and creditor rights (scale of 0 to 5 ). The majority of the advanced countries obtain the highest value in the rule of law measure, while some of the lower income 
countries scoring substantially lower than the maximum 10 score. There is greater variation in the protections given to shareholders and creditors, at least by these measures. The US, for instance, provides considerable anti-director protection while Italy does not; whereas the UK provides considerable creditor rights while France does not. La Porta et al (1999) show that the different legal codes produce different corporate valuations, but do not attempt to link these institutional differences to differences in aggregate national economic outcomes.

\section{f. Summary}

The evidence in this section shows that UK governments have made considerable progress in reforming the economy in a pro-market direction over the past two decades. In the late 1970s the UK was ranked near the middle of all advanced countries in terms of the market friendliness of its institutions. Some indices put the UK even further down, reflecting such factors as the relatively high rate of government ownership, exchange rate controls, and high marginal tax rates. By the late 1990s, the UK stood at or near the top of the rankings - close to and in some cases even ahead of the US. To the extent that orthodox economic thinking is correct and a greater market orientation of policy and institutions means better functioning markets and superior economic outcomes, the UK should have benefitted from these reforms by an improvement in its relative economic performance. What in fact happened?

\section{Trends in UK Economic Performance, 1960-1999}

In this section we analyze the economic performance of the UK relative to the US and its major EU peers, France and Germany, from 1960 to 2000. We focus on the relative trends in aggregate output per capita, and on the associated trends in output per unit of labor input and labor input per capita. There are several reasons for this narrow focus. First, output per capita is the subject of many international comparisons, and policy-makers regularly monitor league tables comparing gross domestic product (GDP) per capita. Second, internationally comparable data on GDP and labor inputs are available for a long period, facilitating an analysis of changes in UK relative performance in these dimensions. Third, 
other macroeconomic indicators, such as the unemployment rate, are highly correlated with labor input per capita . Finally, and most importantly, although conventional economic reasoning says that marketoriented reforms will raise total income, there is no claim that such reforms will improve other potentially important outcomes, such as the poverty rate or the distribution of income. Advocates for marketoriented reforms usually emphasize the goal of increasing income. Taken on their own terms, then, it is important to evaluate the effect of the UK reforms on total market income.

As a starting point, Table 8 presents data from the U.S. Bureau of Labor Statistics (BLS) on the level and rank of GDP per capita for 13 leading countries. Real GDP figures for each country have been converted to a common currency (1998 US dollars) using purchasing power parity (PPP) adjusted exchange rates. ${ }^{12}$ A comparison of 1960 and 1979 figures for the UK suggests that prior to 1980 UK relative economic performance was declining relative to the US (from 74 to 68 percent of the US average) and relative to most other countries, including Germany and France. In 1960 UK output per capita was similar to the level in West Germany and 15 percent higher than in France. By 1979, GDP per capita in Britain was 15 percent lower than in West Germany, 12 percent lower than in France, and a little lower than in Italy. Britain's position in the league table fell from $3^{\text {rd }}$ to $12^{\text {th }}$. Over the 1980 s and 1990 s the UK did better. Relative to the US, per capita GDP in Britain fell slightly, from 68 to 66 percent of the US average. Relative to Germany and France the UK gained slightly. Nevertheless, the UK remained $12^{\text {th }}$ among the 13 countries in the table.

The comparisons in Table 8 open up a series of questions about how the UK might have done absent its market reforms. Would UK output per capita have continued to decline relative to other countries in the 1980s and 1990s in the absence of a sustained reform effort? Or, was the relative decline

\footnotetext{
${ }^{12}$ The PPP factors used by the BLS are very similar to those used by OECD. For the time periods shown in the table, the use of PPP-adjusted real GDP (versus GDP at market exchange rates) mainly effects cross-country comparisons in 1980. PPP factors suggest that exchange rates for most European countries (except the UK and Italy) were significantly over-valued relative to the US. Thus, 1980 PPPadjusted real GDP figures for Germany and France are 30 percent lower than market-based figures, while PPP-adjusted GDP figures for the Nordic countries are 60 percent lower.
} 
of the UK in the 1960s and 1970s driven by particular forces that would have come to end anyway? To help answer this question we delve into the sources of differential growth of the UK and three key competitors: Germany, France, and the US in the pre-1980 and post-1980 periods. We also present some limited comparisons with Italy and Ireland.

\section{a. Trends in the Growth Rates of GDP per Capita and Its Components}

Tables 9 and 10 summarize decompositions of the changes in the relative rate of growth of GDP per working age adult (age 15-64 in most cases) between the UK and the key comparison countries. We analyze GDP per working age adult rather than GDP per capita to remove the variation in per capita GDP that is attributable to shifts in the fraction of children or elderly in the population, and that are thus independent of economic reforms. ${ }^{13}$ The first three columns of Table 9 present the rates of growth of GDP per working age adult in the 1960-1979 and 1979-1999 periods for each country. The underlying data for the UK, the US, and Germany and France, which we plot in Figure $1,{ }^{14}$ show that the UK had slower growth in output per working age adult than Germany or France in the 1960s and 1970s, but somewhat faster growth than the US. The UK also grew more slowly than Italy or Ireland. After 1979, the UK and the US experienced similar growth rates of around 2.0 percent per year while Germany, France, and Italy had slower growth. Only Ireland, which achieved a 3.7 percent annual grow th rate in real GDP per working age adult, out-performed the UK and US in the 1980s and 1990s. In terms of changes in growth rates before and after 1979 the UK performed well relative to Germany, France, and Italy, and about the same as the US.

The growth rate in GDP per working age adult can be decomposed into the sum of the growth rate in GDP per unit of labor input and the growth in labor input per working age adult. The upper panel

\footnotetext{
${ }^{13}$ The data on population are taken from US Bureau of Labor Statistics (2000a). Appendix Table 1 presents data on the changing shares of young and old people in the populations of the UK, Germany, France, Italy, Ireland, and the US.

${ }^{14}$ The series for West Germany and France track each other very closely and we have averaged them to avoid clutter in the graphs.
} 
of Table 9 presents this decomposition using employment per working age adult as a measure of labor input, while the lower panel shows a decomposition based on hours of work per working age adult. The underlying series for the UK, Germany, France, and the US are plotted in Figures 2 and 3. ${ }^{15}$ The figures show that all countries experienced a slowdown in the rate of growth of productivity after 1979 . The slow down was bigger in Germany, France, and Italy than in the UK, and bigger in the UK than the US. Compared to the 1960 s and 1970 s, when growth rates in output per worker ranged from 1.6 percent per year in the US to 3.6 percent per year in Germany and France, the grow th rates of output per worker in the 1980 s and 1990 s were remarkably similar across countries. The same story characterizes the growth rates in GDP per hour. In the 1960s and 1970s the UK lagged about 1 percent per year behind Germany and France in the growth of productivity per hour and even further behind Italy, but after 1979 productivity per hour grew at similar rates in all four countries.

Unlike the productivity trends, which converged across countries in the post-1979 period, trends in labor input show little evidence of convergence. Prior to 1979, the UK, Germany, France, Italy, and Ireland all had declining employment-population rates, although the rate of decline was slower in the UK than elsewhere in Europe. After 1979, the UK (and Ireland) moved to a more "US-like" pattern of rising employment rates, while Germany, France and Italy continued to experience declining employment rates, albeit at a slower pace than pre-1979. Hours per working age adult show a similar pattern of divergence. In Germany, France, and Italy, hours declined at about 3/4 to 1 percent per year in the $1980 \mathrm{~s}$ and $1990 \mathrm{~s}$, whereas in the UK the post-1979 trend was negligible, and in the US the trend was positive.

The implications of these shifting trends in productivity and labor input in the UK relative to other countries are summarized in Table 10. The first column of the table shows the growth rate in GDP per working age adult in the UK relative to a particular comparison country. The second and third columns divide this difference into differences in the growth of GDP per worker and employment per

\footnotetext{
${ }^{15}$ For reference, Appendix Table 2 presents data on employment-population rates and average hours per working age adult for the various countries.
} 
working age adult, while the fourth and fifth columns divide the difference into relative growth of GDP per hour and hours per working age adult. Panel A decomposes relative growth rates in the "pre-reform" period (1960-79), panel B decomposes grow th rates in the "reform" period (1979-1999), and panel C shows the decomposition of the relative change in growth rates between the two periods. For example, panel A shows that in the $1960-79$ period the UK had 0.63 percent per year slower growth in GDP per working age adult than in West Germany, and 1.02 percent per year slow er growth than in France. This resulted from slower relative productivity growth in the UK dominating a more modest decline in the growth of labor inputs. Relative to the US, on the other hand, the UK had 0.48 percent faster growth in GDP per working age adult in the 1960 s and 1970 s, due to relatively faster productivity growth dominating a relative decline in labor inputs.

Panel B shows that in the post-1980 reform era, UK productivity growth was roughly comparable to rates in Germany and France, but the UK had stable or rising labor inputs while Germany, France and most other European nations experienced continuing declines. Thus, the 0.8 percent per year faster growth in UK GDP per working age adult relative to Germany or France in the 1980s and 1990s was attributable almost entirely to the growth in labor inputs. Again, the contrast with the US is different: relative to the US, the UK had somewhat faster growing productivity but slower growth in labor inputs.

Finally, Panel C shows that the UK accelerated its economic performance relative to West Germany and France in the post-reform period. Relative to Germany, the differential in GDP growth per working age adult shifted from -0.63 percent per year in the pre-reform era to +0.84 percent per year in the reform era, for a net relative gain of 1.47 percent per year. Regardless of whether labor inputs are measured by employment or hours, most of this relative gain is attributable to the larger drop in productivity in Germany and France than in the UK. A fairly similar story emerges in the comparison to France, although in this case a larger fraction of the UK's relative improvement is attributable to a relative gain in labor inputs in the UK. Benchmarked to the US economy, however, the UK does not fare as well. In the 1960s and 1970s the UK had faster productivity growth than the US, but this was partially offset by 
relative declines in per capita labor inputs. After 1979 productivity growth slowed down everywhere, but more in the UK than in the US, though productivity growth rates were still faster in the UK (see Figures $3 \mathrm{~A}$ and $4 \mathrm{~A}$ ). This was only partially offset by the bigger turnaround in the trend toward declining work activity in the UK.

Tables 9 and 10 show that the reform era coincided with a reversal of the faster growth in GDP per working age adult in Germany and France than in the UK, due mainly to the slower deceleration in productivity growth in the UK. They also show that after 1979 UK labor productivity grew at about the same rate as in Germany and France, but Britain had stable or slightly rising labor inputs per capita, while Germany and France had declining labor inputs. This relative rise in work effort led to higher growth rates in British GDP per capita after 1979. Finally, the tables show no apparent turnaround in UK performance relative to the US. Indeed, the comparison of the US to the UK has the same character as the comparison of the UK to Germany/France. The US had a smaller productivity slowdown than the UK and a bigger rise in the rate of growth of labor inputs, with the net result that GDP per capita rose faster in the US than the UK after 1979, whereas the opposite was true before 1979.

\section{b. Explanations for Differential Trends in Labor Productivity Growth}

Much of the improvement in UK economic performance relative to Germany and France is attributable to the closing of the gap in productivity growth rates. Similarly, the worsened performance of the UK compared to the US in the post-1979 period relative to earlier decades is due mainly to the narrowing of productivity growth rate differentials. In this section we consider three explanations for the shifting trends in labour productivity growth: relative trends in the transition out of agriculture, relative trends in the rate of growth of capital per unit of labor input; and relative trends in the quality of labor.

\section{(i) The Shift Out of Agriculture}

One widely recognized source of economic growth is the movement of labor from low productivity sectors such as agriculture to more highly productive sectors such as manufacturing and 
distribution (e.g. Feinstein, 1999). By 1960, only 5 percent of workers in the UK were employed in agriculture. In West Germany and France, however, the fractions were 14 and 23 percent, respectively. The fall in agricultural employment in these countries in the 1960s and 1970s can explain some of their rapid productivity growth in this period. To the extent that the movement out of agriculture was complete by the late 1970s, the slowdown in employment reallocation can also help explain the greater slowdown in productivity growth experienced by Germany and France than the UK or the US. Table 11 presents a share-shift analysis of the effects of declining agricultural employment on aggregate productivity growth rates in the pre-1979 and post-1979 periods. ${ }^{16}$ To a first order approximation, the change in aggregate productivity associated with a shift $\Delta \mathrm{S}$ in the share of agricultural employment is $-\Delta \mathrm{S} \times(1-\mathrm{R})$, where $\mathrm{R}$ is relative productivity in agriculture. The entries in columns 4 and 5, drawn from sectoral productivity data reported by van Ark (1996), show that R was about 33 percent in the UK and France, 18 percent in Germany, and 60 percent in the US in the early 1960s. In light of these differentials, the 8.7 percentage point decline in the share of agricultural employment in Germany in the 1960-79 period contributed about 0.4 percent per year to the trend rate of growth of labor productivity, while the 14.4 percentage point decline in France contributed about 0.5 percent per year. By comparison, the much smaller shifts in the UK and the US had negligible impacts on aggregate productivity (less than 0.1 percent per year). In the 1979-98 period the contributions of the movement out of agriculture were small in all four countries, but particularly in the UK and US. These calculations suggest that the declining share of agricultural employment can explain one-quarter to one- third of the faster productivity growth of Germany/France than the UK in the pre-1979 period ${ }^{17}$. The slowdown in sectoral reallocation explains about the same fraction of the 1.2-1.4 percentage point faster slowdown in productivity growth in Germany/France than

\footnotetext{
${ }^{16}$ Appendix Table 3 presents employment shares in three sectors: agriculture, industry, and services.

${ }^{17}$ That is the differential shift explains 0.3 to 0.4 percent per year of the 1.2 percent per year gap in the growth in productivity per worker.
} 
the UK after 1979. As these effects are presumably independent of the reform process in the UK, we will factor them out before attempting to evaluate the contribution of the UK reforms.

\section{(ii) Changes in the Capital-labor Ratio}

Standard growth accounting exercises decompose the growth rate of labor productivity into three components: changes in the amount of capital available per unit of labor input; changes in the "quality" of labor inputs; and technological change or other efficiency improvements. ${ }^{18}$ Specifically, assuming a constant returns to scale aggregate production function,

(1) $\Delta \log (\mathrm{Y} / \mathrm{L}) \approx \alpha \Delta \log \mathrm{q}+(1-\alpha) \Delta \log (\mathrm{K} / \mathrm{L})+\Delta \log \mathrm{A}$

where $\Delta \log \mathrm{x}$ represents the logarithmic differential (or percentage change) in the variable $\mathrm{x}, \mathrm{Y} / \mathrm{L}$ represents real output per unit of labor input, $\mathrm{q}$ is the relative quality of labor inputs, $\mathrm{K} / \mathrm{L}$ represents real capital per unit of labor input, $\alpha$ represents labor's share (the cost of labor inputs divided by the value of output), and $\mathrm{A}$ is an index of overall efficiency. Since different institutions and policies potentially affect the accumulation of physical and human capital, and the rate of growth of technological efficiency, we next decompose the shifts in the relative trends of UK labor productivity into these three components.

Figure 4 plots the trends in capital per worker for the UK, West Germany, France, and the US from 1960 to 1999, using data on real net physical capital stocks from Mary O’Mahoney. To maximize international comparability, O'Mahoney's series use a consistent set of geometric depreciation factors. Similarly, for consistency with the practices in other countries, the underlying investment series for computer related equipment in the US have been deflated by a traditional cost-based index, rather than by the hedonic price index developed by the US Bureau of Economic Analysis (BEA) (see O’Mahoney, 1996, pp. 174-176). Consequently, the growth rate of the US capital stock in the 1990s is somewhat

\footnotetext{
${ }^{18}$ See e.g. Griliches (1970). In this framework, sectoral shifts can be modeled as efficiency improvements.
} 
slower than shown by official BEA data. ${ }^{19}$ The data in Figure 4 show that the growth rate in capital per worker was faster in all three European countries than in the US both before and after 1979. UK growth rates in capital per worker are very similar to those in West Germany, but slower than those in France in the 1980 s and early 1990 s.

If labor's share is constant, then equation (1) implies that we can adjust the observed grow th in labor productivity for the effects of rising capital per unit of labor input by subtracting $(1-\alpha)$ times the growth rate in capital per unit of labor. This exercise is carried out in Table 12. As in previous tables, we consider two measures of labor input: employment, and total hours. The first three columns of the table reproduce the estimated trends in GDP per unit of labor input from the middle of Table 9. Columns 4-6 show the corresponding trends in capital per unit of labor. Finally, columns 7-9 report estimates of productivity growth rates in the pre-reform and post-reform eras, adjusted for changing capital intensity. In these calculations we use an estimate of labor's share of 0.65 for all four countries. In view of this over-simplification, the estimates in columns 7-9 should be interpreted as rough guides to the adjusted productivity growth rates that would emerge from a more detailed calculation. ${ }^{20}$

We draw three conclusions from Table 12. First, the growth rates in capital per unit of labor were similar in the UK, West Germany, and France in the pre-1979 period. Thus, the relatively slow rate of UK productivity growth in the pre-reform period does not reflect a shortfall in investment relative to employment growth. ${ }^{21}$ Second, in all three countries the growth in capital per unit of labor input slowed dramatically after 1979. In the reform era capital per unit of labor input grew at about the same pace in

\footnotetext{
${ }^{19}$ The capital series for all four countries are very highly correlated $(r>0.99)$ with the series in the OECD International Sectoral Database (1999 edition), and with an alternative set of series constructed by O'Mahoney (1996) using somewhat different methods.

${ }^{20}$ Blanchard (1997) presents an interesting analysis of the sources of variation in labor's share over time. In the UK, labor's share of GDP was $65.9 \%$ in $1960,69.0 \%$ in $1970,68.5 \%$ in $1980,65.9 \%$ in 19990, and 62.3\% in 1996 (Office of National Statistics, 1997, Table 1.4).

${ }^{21}$ Recall from Table 9 that in the 1960-79 period labor inputs per capita grew a little faster in the UK than in Germany or France. So investment per capita grew slightly faster in the UK too.
} 
the UK as in West Germany (especially when labor input is measured on an hours basis), and somewhat slower than in France. Based on these comparisons, we believe that investment is not the primary mechanism behind the gains in UK productivity growth relative to its European competitors in the period of market reforms. For example, using an hours-based measure of labor inputs, the UK had a 1.21 percent per year gain in the rate of growth of productivity relative to West Germany after 1979 (see Panel $\mathrm{C}$ of Table 10). After adjusting for the impact of changing trends in capital per hour, the relative gain was $1.10(-0.15+1.25)$. Similarly, the gain relative to France in the growth of productivity per hour was 1.21 percentage points per year: after adjusting for shifting trends in capital per hour, the relative gain was slightly larger $(1.43=-0.15+1.58)$.

But changing trends in capital growth per unit of labor input go a long way toward explaining the changing relative trends in productivity growth between the UK and the US. Capital accumulation per worker slowed less in the US than in the UK (or Germany/France), and after adjusting for this fact, the trend rates of growth of productivity are very similar in the UK and US. Using an hours-based measure of labor input, the trend grow th rate in productivity in the UK net of capital was 1.57 percent per year in 1960-79, compared to a rate of 1.41 percent per year in the US. In 1979-99 the trend growth in UK productivity net of capital was 1.42 percent per year compared to 1.40 percent per year in the US. Thus, the changing relative trends in productivity growth between the two countries are well explained by the changing relative trends in capital per worker.

(iii) Changes in Labor Quality

A final source of growth in labor productivity is rising labor quality, driven by increases in educational attainment or shifts in other skill characteristics of the labor force. Available data suggests that the rise in formal education qualifications was bigger in the UK than in Germany (e.g., Broadberry and Wagner, 1996), although the disappearance of the apprenticeship system in the UK (Blanchflower and Lynch, 1994) suggests that Britain has fallen behind other European countries in one area of skill 
formation. We evaluate the impact of changing labor quality on productivity by: 1) estimating a microlevel wage equation which relates individual earnings to observed characteristics such as education, vocational qualifications, gender, and age; and 2) by using the estimated coefficients in a base year to evaluate the changes in the relative quality of the labor force by calculating average predicted wages for workers in two different years, and forming the ratio of these averages (see Griliches, 1970). ${ }^{22}$ This method weights changes in different characteristics by the same market metric (relative earnings) that und erlies the construction of GDP statistics. A problem is that coefficients from different base years will give different estimates of the change in labor quality when the market returns to different skill characteristics change over time.

We use different data sets for different countries in this analysis. For the UK, there is no single micro data source that spans the past four decades. The best available source is the General Household Survey (GHS), which has sampled roughly 10,000 workers each year from 1974 onward, and includes detailed information on both academic and vocational qualifications. We use GHS data to estimate changing labor quality in the UK over the period from 1975 to 1996 . For the US, the March Current Population Survey (CPS) provides annual data from 1967 onward. Comparable data were collected in the 1960 Census. Pooling there data sources it is possible to construct estimates of changing labor quality in the US economy over the 1959-99 period. For Germany there are no publically available data sets comparable to the GHS or CPS. The German Socio-Economic Panel (GSOEP) provides micro data for a fixed panel of households starting in the early 1980s. Detailed cross-tabulations of the age, education, and gender distribution of the German labor force (based on the Mikrozensus) are available irregularly starting in 1976. We use a combination of the GSOEP micro data (to estimate the coefficients) and the Mikrozensus cross-tabulations to estimate changes in West German labor force quality over the period from 1976 to 1999 . We drop France from our analysis due to the absence of publicly available micro data

\footnotetext{
${ }^{22}$ In practice, we constructed weighted averages that weight each worker by his or her relative hours of work.
} 
sets on labor skills and earnings over time.

Table 13 summarizes our estimates of the relative rates of change in the quality of labor in the UK, West Germany, and the US. For the UK, our micro level wage model includes a measure of years of total schooling, dummies for three levels of academic qualifications (university degree, A-levels, 3 or more O-levels), dummies for three levels of vocational qualifications, and dummies for ten 5-year age categories, fully interacted with gender. The estimates in Table 13 use coefficients from a model fit to 1984-86 data. ${ }^{23}$ The implied rates of growth in labor quality are about 0.2 percentage points per year in the late $1970 \mathrm{~s}$ and 0.9 percentage points per year in the $1980 \mathrm{~s}$ and $1990 \mathrm{~s}$. The relatively rapid pace of quality growth in the 1980 s and 1990 s reflects a substantial rise in average education among UK workers $(+1.75$ years from the mid-1970s to the mid-1990s) coupled with rises in the fractions of workers with university degrees and vocational qualifications (see Appendix Table 4). Offsetting these gains was a 10 percentage point rise in the fraction of women. Since women earn substantially less than men, this trend has slowed down the growth of labor force quality in the UK.

For West Germany, our wage determination model includes a full set of interactions of gender with eleven 5-year age categories and five education categories. These 110 cells represent the finest level of detail available in published cross-tabulations of age, education, and gender from the Mikrozensus. ${ }^{24}$ Compared to the UK, the rate of growth of labor quality in West Germany was relatively high in the late 1970 s but much slower in the 1980s and 1990s. This is because the distribution of workers across

\footnotetext{
${ }^{23}$ We use this for comparability with the German model, which is fit to 1985 GSOEP data. Use of estimated coefficients from earlier years give slightly slower rates of growth, since the wage disadvantage for women is higher and the return to education is lower. Estimates from later years give higher rates of growth of quality.

${ }^{24}$ The education categories are: a regular university degree (or more); a technical college degree; a "meister" (master craftsman) qualification; a completed apprenticeship; and a residual category that includes those with only a high school education and those who started but did not finish a postsecondary program. The 1999 cross-tabulations include all of Germany. This may lead to some downward bias in the trend in education over the 1980-99 period. Over the 1980-89 period the trends is similar to that observed over the longer period.
} 
education categories in Germany changed only modestly, while fraction of female workers increased from 38 percent in 1980 to 43 percent in 1999.

For the US our wage determination model includes years of education, a dummy for a college degree, dummies for nonwhite race and Hispanic ethnicity, and full interactions of gender with ten age categories. Over the 1959-79 period we estimate that the average quality of the US workforce rose by about 0.3 percent per year. The main contributors were a rise in average education (from 10.5 to 12.4 years) and in the fraction of workers with a college degree (from 8.8 to 17.5 percent). Working against this trend were a rise in the fraction of young workers (from 31 percent under the age of 31 to 41 percent) and a 10 percentage point rise in the fraction of women (from 35 to 45 percent). Over the 1980 s and 1990s our model suggests that labor force quality growth was a little faster than in the 1960s and 1970s, despite a slowdown in the rate of growth of average years of education. Contributing factors were a drop in the fraction of young workers and a dramatic slowdown in the entry of women.

The key conclusion from Table 13 is that labor force quality grew faster in the UK in the post1979 reform era than in West Germany or the US. The differential relative to Germany is 0.66 percentage points per year. Assuming that labor's share is 65 percent, this gap would be expected to lead to about 0.4 percentage points per year faster growth in labor productivity in the UK than in Germany. A similar calculation suggests that relative improvements in labor force quality contributed to a 0.3 percentage point per year difference in productivity growth relative to the US. Since column 8 of table 12 shows that labor productivity adjusted for trends in capital grew at about the same rate in all three countries in the 1979-98 period, the implication is that UK productivity growth net of labor quality growth was slower than expected in the reform era, relative to Germany and the US. The absence of data on the characteristics of UK and German workers in the 1960s, preclude any definitive assessment of whether shifts in the trend grow th in labor quality can account for the bigger slow dow $\mathrm{n}$ in productivity growth in West Germany than Britain. Extrapolating from limited data for the late 1970s, it appears that the growth rate of labor force quality accelerated in the UK and declined in Germany after 1979/80. These 
patterns are consistent with the relative changes in productivity growth rates.

(iv) Summary of Changing Trends in Productivity Growth

Table 14 summarizes our attempt to decompose productivity growth in the UK, West Germany, France, and the US into components attributable to the movement out of agriculture, the rise in capital per unit of labor input, and changing labor quality. For simplicity, we focus on trends in productivity per hour $^{25}$. Sectoral shifts out of agriculture help explain some of the more rapid productivity growth of France and Germany relative to the UK (or US) prior to 1979. After 1979, most of the adjustment was complete, leading to a bigger productivity slowdown for France and Germany than the UK or US. Increasing capital per unit of labor is an important component of productivity growth in all countries. Trend rates of capital growth are similar in the UK, Germany, and France, however, suggesting that relative investment trends have not been a major source of differential productivity growth among these three countries. The slowdown in capital accumulation was smaller in the US, and an adjustment for capital brings the productivity trends in the US and the UK into close alignment.

Adjusting for sectoral shifts and capital trends, the productivity growth rate in the UK in the 1960-79 period was 1.5 percent per year -0.7 to 0.9 percent per year lower than in West Germany or France, but 0.2 percent per year higher than in the US. Given the limitations of the available data we are unable to estimate how much of the gap between the UK and its major European competitors was due to slower growth in labor quality: we suspect this may be a part of the story for the UK-Germany differential. After 1979 adjusted UK productivity growth was 1.4 percent per year - only slightly below the rate in the previous decades, and about equal to the rates in Germany, France, and the US. We estimate that the UK had somewhat faster growth in labor quality than Germany or the US in the 1980s and 1990s. The growth rate in productivity in the UK attributable to efficiency gains, technological

\footnotetext{
${ }^{25}$ The calculations for trends in productivity per worker are similar.
} 
change, and other unobserved factors was therefore slower than in West Germany or the US.

The bottom line is that while the various factors that we have examined explain some of the improved relative performance of the UK in the era of market reforms, there still remains an upswing in the growth of GDP per working age adult (and per capita) in the UK compared to its major EU competitors.

\section{Relating Reforms to Performance}

Did the economic reforms adopted in the UK in the 1980s and 1990s cause the changes in economic performance documented in the previous section? Given the complexity and overlapping nature of the reforms, and the difficulty of specifying what would have happened in the UK economy in the absence of reform, this is a difficult question. Rather than attempt to answer it, we address a more modest question: is there a plausible link between some of the major reforms and the economic changes we have identified? Our analysis highlights two key facets of the change in the economic performance of the British economy after 1979:

1. (Productivity). Pre-1979, UK productivity growth was about 1 percent per year slower than in Germany or France (net of sectoral shifts). After 1979 the gap disappeared. None of the convergence is explained by trends in capital accumulation; some may be due to rising labor quality in the UK. After adjusting for trends in capital accumulation, trends in relative productivity growth in the UK and US were very similar before and after 1979.

2. (W ork Effort). Pre-1979, employment rates and hours per capita were declining more slowly in the UK than Germany/France. After 1979 this difference widened, contributing to faster growth in GDP per capita. Although work effort rose relative to Germany and France, it has not kept pace with trends in the US.

Potential explanations for the productivity results include reforms that lowered barriers to productivity growth in the UK, or that generated once-for-all increases in the productivity of UK 
businesses. Potential explanations for the work effort results include reforms that increased the incentives for work in the UK relative to continental Europe.

\section{a. Productivity-enhancing Reforms}

Many UK policy reforms could have contributed to rising labor productivity, including laws that have weakened the coverage and power of trade unions, leading to changes in union policies; privatization of nationalized industries; the creation of incentives for self employment and share ownership.

Some of the most prominent early reforms introduced by Mrs. Thatcher were designed to reduce trade union power. The Employment Acts of 1980,1982, and 1984 limited secondary picketing, abolished statutory union recognition procedures, weakened the closed shop, and mandated changes to internal union governance (including compulsory pre-strike balloting). In addition, other government actions, such as the privatization of highly unionized state-owned industries and the removal of contract requirements to pay union-negotiated wages, substantially weakened the government's indirect support for unionism and collective bargaining (Pencavel, 2002). Union membership rates, which had reached a peak of over 50 percent in 1980, declined steadily in the subsequent decades and by 1999 stood at under 30 percent of wage and salary workers (see Appendix Table 5). Strike activity plummeted in the 1980s (Pencavel, 2002). The presence of multiple unions in the same work place, which contributed to some of the worst excesses of British industrial relations in the pre-1980 period, also fell. The evidence shows that the relationship between productivity and collective bargaining shifted in this period. Using data from the Workplace Industrial Relations Survey (WIRS) conducted in 1998, Pencavel (2002) concludes that by the end of the 1990 s unionized establishments were no less productive on average than their nonunion counterparts. By comparison, Pencavel's analysis of similar data from the 1990 WIRS, and studies by other researchers (e.g., Machin, Stewart, and van Reenan, 1993) suggest that unionized establishments suffered a significant productivity disadvantage in earlier years. 
These findings suggest that reforms linked to reductions in trade union power had some impact on measured UK productivity. For example, if the 43 percent of private sector employees in 1979 that were working in unionized establishments had 10 percent lower productivity than other workers, then the elimination of the union productivity gap could contribute to a 4.3 percentage point gain in aggregate productivity between 1979 and 1999. Some analysts have argued that the changed industrial relations climate in the UK has led to a permanent shift in the productivity growth rate (Bean and Crafts, 1996). However, the empirical analysis on this is relatively limited (see Pencavel, 2002), and we regard the 4.3 percentage point gain over the entire period as a generous upper bound on the potential gains associated with elimination of the negative productivity effect of trade unions. ${ }^{26}$

What about the effect of privatization of industries on productivity? In $197912 \%$ of UK GDP was produced in publicly owned companies; in 1997, just $2 \%$ of UK GDP was produced in publicly owned companies. While, as Haskell and Green (2002) show, productivity grow th was not the primary impetus for privatization in the early Thatcher years, the widespread belief that private businesses operate more efficiently than state-run businesses suggests that privatization of this magnitude could have contributed to the improvement in relative productivity in the 1970s-1990s. Their industry-level evidence shows that privatization per se had no large effect on productivity, but that in many cases productivity increased in the period before privatization as the government sought to improve operations in order to make the business attractive to the private sector. Labor productivity between 1980 and 1992 went up for plants that were public in 1980 and private in 1992, with the increase concentrated in the period

\footnotetext{
${ }^{26}$ One way in which unions might in theory have reduced labor productivity is by causing firms to invest less through a "hold-up" effect: a unionized firm that invests in new equipment can expect to have to pay higher wages in the future, thereby reducing the effective return on capital (Grout 1984). Our evidence gives no indication that this occurred in the UK. Despite the decline in unionization rates in the UK, and the apparent shift toward more co-operative relations with employers, the rate of growth of capital per worker (or capital per hour) did not accelerate in the UK relative to West Germany or France. Either the under-investment effect was relatively small before the reforms of the 1980s and 1990s, or deunionization and an improved industrial relations climate have had little effect on the investment calculus of British employers.
} 
immediately preceding privatization. They, and other analysts, have stressed that increased competition after privatization appears to be the key factor differentiating sectors where privatization was associated with improved productivity and sectors where it was associated with stagnation or declines in productivity relative to private firms or international benchmarks.

To get a rough estimate of how much this might have added to aggregate productivity growth, we assume, as they do, that the process of privatization accounts for this improvement. Appendix Table 7 shows that $1.4 \%$ of the UK workforce was employed in nationalized industries in 1995 compared to $7.3 \%$ of the UK workforce in 1975 , which indicates that privatization shifted nearly $6 \%$ of the work force from the public to private sector. While there is no single "best" estimate of the effect of privatization on productivity, a generous estimate based on Haskell and Green's plant data (Table 6, labour productivity line) is that privatization induced a gain in labour productivity of nearly $20 \%$ above the private sector increase. This would imply an increase in aggregate productivity of $1.1 \%$ between 1979 and $1999 .{ }^{27} \mathrm{We}$ regard this as a generous upper bound on the potential gains associated with privatization since it gives all of the privatized sectors the $19 \%$ gain, whereas productivity did not in fact improve in some industries.

Another area where the UK has made major micro market-oriented changes is in the introduction of various "shared compensation" programs which give employees a stake in the firm performs, either through profit-sharing or share ownership. Evidence in Conyon and Freeman (2001) shows that productivity is higher in firms that have such programs compared to those that do not have such programs. Not all of the programs that the UK government has favoured with tax relief have a positive impact on productivity, but the most important programs -- the approved profit sharing scheme introduced in the 1978 Finance Act, which the government replaced with an all-employee share plan in 2000 -- has an estimated productivity effect in the area of $10 \%$ (Canyon and Freeman, 2002, Exhibit 5c, based on

\footnotetext{
${ }^{27}$ Our $1.2 \%$ estimate comes from taking the 1992-1980 rate of productivity growth in the plants that moved from public to private of $.44 \log$ points, subtracting the 1992-1980 productivity growth of private plants $(.27 \log$ points) to obtain a privatization boon of $.17 \log$ points, which is $19 \%$. Multiplying this by the 6 percentage point shift gives an estimate of $1.1 \%$.
} 
stock market returns) to $18 \%$ (exhibit 4 , based on production function estimates). Millward, Bryson, and Forth (2000, Table 6.13) show that there was an increase in the proportion of industry and commerce establishments with 25 or more employees having profit-sharing plans from $19 \%$ in 1984 to $46 \%$ in 1998 . Inland Revenue data also show a large increase in the number of workers who received tax advantaged payments under government approved profit-related schemes. In 1979 approximately one quarter as many workers were likely to have been covered by plans. ${ }^{28}$ On the basis of the establishment surveys and Inland Revenue data, we estimate that the proportion of British workers covered by these plans increased by approximately 20 percentage points. This implies a gain in productivity gain on the order of $2.0 \%$ to as high as $3.8 \% .^{29}$

The British reforms also encouraged workers to become self-employed. Appendix Table 6 shows that the proportion of the work force in the UK that was self-employed rose from $8.4 \%$ in 1980 to $13.1 \%$ in 1990 , and then stabilized. Over the entire period, the proportion self-employed rose by 4.3 percentage points. In general, self-employed workers earn less than wage and salary workers, with about a $10 \%$ differential between the two. Interpreting this differential as the result of differences in productivity, the implication is that this reform reduced productivity by 0.4 percent. By contrast, the percentage of workers who were self-employed in Germany and the US fell over this period, with the decline in German self-employment due largely to the drop in agricultural employment.

Summing up the estimated effects on productivity of the change in the relation between unionism and productivity $(4.3 \%)$, privatization $(1.1 \%)$, profit and share ownership schemes $(2.0 \%)$ and self-

\footnotetext{
${ }^{28}$ Inland Revenue Service, Employee Share Schemes and Profit-Related Pay: Table 6.1 http://www.inlandrevenue.gov.uk/stats/ gives the number of workers who actually received payments under various schemes. 225,000 received payments in 1979 under the Finance Act of that year compared to 960,000 in 1907-98, but an additional 1,170,000 employees were granted options under the Finance Act of 1980. Since workers may be covered by plans but not receive payments in a given year, these data show a big trend but smaller magnitudes than in the establishment survey.

${ }^{29} \mathrm{We}$ base this estimate by multiplying the $10 \%$ productivity effect by the 20 point increase in the proportion of workers covered by profit-sharing option plans.
} 
employment $(-0.4 \%)$, we estimate the micro-evidence of the effect of particular reforms on productivity may have raised UK productivity on the order of $7 \%$ or approximately $0.35 \%$ per year, which is about one quarter of the difference in growth rates between the pre-reform 1960-79 and the 1979-99 reform period shown in part $\mathrm{C}$ of Table 10, and a potentially higher proportion of growth rates adjusted for the improved quality of the work force. These estimates are, to be sure, crude. They are based solely on changes in the UK rather than changes in the UK relative to other countries, though we have seen that the UK reforms were considerably greater than those in France, Germany, and the US. What we conclude is that the estimated effects of the micro-reforms cumulate to an order of magnitude that suggests that they explain part of the acceleration in UK productivity growth compared to Germany or France.

\section{b. Reforms in the Incentives for Work}

Many important reforms have affected the economic incentives for work in the UK relative to other advanced countries, including West Germany and France. These include changes that lowered the generosity and availability of unemployment benefits; taxation of various previously untaxed socially provided benefits, elimination of the earnings-related supplement, suspension of indexing of benefit levels for several years in the 1980 s, elimination of unemployment benefits for young people, establishment of the ReStart and later New Deal programs to monitor job search effort of benefit claimants (van Reenan, 2002); lowering of marginal tax rates; and the introduction of the Family Credit in 1988 and ensuing 1999 Working Families Tax Credit (WFTC) to improve the work incentives for families with low incomes (Hoynes and Blundell, 2002); reforms in pensions designed to increase labor mobility. The Thatcher era reforms sought to increase the incentive to work (Blanchflower and Freeman, 1993) and ensuing reforms had a similar intent. If these reforms exceeded those in France and Germany, they might help explain the improved employment rate in the UK versus those (and other) advanced OECD countries.

Consistent with the picture given by our indices on the labor market (Tables 5 and 6), it appears 
that in some dimensions that might affect employment, the UK did indeed undertake greater marketoriented changes than other advanced countries. Table 15 shows that from 1965-72 to 1988-95 the UK reduced the average replacement rate of the unemployment benefit system (the ratio of unemployment benefits to the previous wage) by more than any other country, so that by the 1990 s it had the lowest rate among covered countries. Because unemployed workers receive other benefits - housing subsidies, child support, and so on - the reduction in support is arguably less than that indicated by the fall in the replacement rate. Still, the table captures the greater effort by the UK than most other countries to reduce the disincentive to work. Studies that look at the impact of changes in the replacement rate and other measures of unemployment benefit on unemployment or employment show that reforms that lessen the payoff and in particular the length of access to benefits tend to increase employment, though only modestly. ${ }^{30}$

Hoynes and Blundell (2002) have examined the shift in UK welfare support toward "in-work" benefits. By shifting support to working families, the WFTC reform should also increase employment. They show, however, that any such effects are relatively small, in large part because UK in-work benefits are counted as income for other benefits, notably rent rebates under the Housing Benefit, so that the effect of these reforms on incentives to work were relatively modest. In addition, the UK increased the generosity of other welfare programs at the same time, further reducing the employment incentive in these reforms. The result is that very little of the rise in the employment rate of women can be plausibly related to these changes. Van Reenan's (2002) analysis of the New Deal programme initiated by the Labour Government gives a similar picture of modest impacts of reforms on employment. In this case, the combination of assistance in job search, wage subsidies to employers, education and training coupled with time limited benefits produced an estimated gain of 17,000 employed young persons - a modest

\footnotetext{
${ }^{30}$ See OECD, Employment Outlook, July 1996, chapter 2, and Atkinson and Mickelwright (1999). The most recent work covering the US tells a similar story, see Ashenfelter, Ashmore, and Deschenes (1999).
} 
amount in an economy with some 27 million workers in 2000.

Some might argue that the decline in union power and increase in inequality that the various labour market reforms helped bring about may have contributed to the expansion of employment. Since unionisation fell rapidly in manufacturing, where employment was decimated, it is difficult to make any sectoral link between changes in union power and growth of jobs. On the wage side, the fact that real wages in the UK rose throughout the 1980s and 1990s makes it hard to tell a story in which declining wages created employment. Similarly, the fact that groups and sectors where wages increased the most had the biggest increase in employment also raises doubts about any simple micro reform-job creation story. The biggest problem in assessing the contribution of the reforms on employment from micro studies is, of course, that the macro-performance of the British economy dominates overall employment patterns. In the 1980 s through the early 1990 s the UK had relatively high unemployment despite the various economic reforms because of poor macro-economic policy and outcomes. The adverse effects of high and rising unemployment masked any positive effects of micro-institutional changes on labor market outcomes. From the mid 1990s to early 2000s the employment-creating effects of an extended boom dominated any impacts of micro-reforms on outcomes. If the market-oriented policy reforms in the labour market contributed to the length and extent of the economic expansion they would indeed help explain the good performance of the UK in employment in this period, but such a contribution cannot be readily determined from micro-economic data.

\section{c. An alternative approach}

There is another way to assess the impact of the UK reforms on economic performance. This is to relate country-level economic performance to indicators of market-oriented institutions and policies such as the Fraser Institute Index (FII), and then use the estimated coefficients to estimate how much the UK reforms affected UK outcomes. As with other cross-country analyses, this procedure has some advantages and disadvantages. On the plus side, it provides a statistical assessment of purported effects 
of reforms, with an explicit counterfactual posed by the economic performance of countries that did not change their regulatory stance. Using the Fraser Institute data from 1970 to 1995 we can estimate models that include country specific fixed effects, thus focusing on the effects of country-specific changes in the regulations and institutional features summarized in the FII. On the negative side, this method does not isolate the effects of reforms in the UK per se. Rather, the estimated coefficients will reflect the combined experience of all the countries that undertook substantial free market reforms, including those that have not done particularly well in recent decades, like New Zealand. Pro-market reforms may have been the right medicine for the UK but not for New Zealand. Or, reforms in countries like New Zealand may have been overpowered by other forces. Still, it is useful to examine what such an analysis shows about the impact of reforms similar to those adopted in the UK on advanced countries in general.

Table 16 records the coefficients and standard errors for a set of cross-country regressions of the level and grow th of various macro-economic outcomes on the Fraser Institute Indexes reported in Table 1. Since the FII is reported every five years, the calculations relate to five year intervals starting in 1970 . When the dependent variable is the log of the level of an outcome, it refers to average over the same five year period. When the dependent variable is the log change in the outcome, it refers to the ensuing five year period: thus, the FII for 1970 is related to the change from 1970 to 1975 . For 1995, the change relates to 1995-1999, adjusted to allow for the fact that this change covers 4 rather than 5 years.

Each line in the table comes from a separate regression. The odd numbered regressions include unrestricted year effects, and are effectively pooled cross-sectional comparisons across countries with different levels of the FII. The even numbered regressions include both year and country dummies: these models relate changes in the dependent variable to changes in the FII within countries, while controlling for average changes across countries that had no change in the value of the FII.

The odd-numbered estimates that have the dependent variable in levels show that countries with greater market freedoms have higher GDP per capita, higher productivity per employee, and higher employment per adult in the population. In part this reflects the fact that the countries with the highest 
FII scores include the US and Canada while those with the lowest scores include Portugal and Greece. By comparison, the odd-numbered estimates with the dependent variable in differences suggest that countries with higher values of the FII have slower growth in GDP per capita and GDP per worker. Again, this presumably reflects that growth rates have tended to be slowest in countries like the US and Canada with higher values of the FII, and faster in countries like Portugal and Greece.

Arguably, more weight should be given to the estimates in the even-number rows, which include country dummies, and therefore reflect the effects of reforms on the levels or growth rates of the macro outcomes, relative to past levels or growth rates in the same country. Examination of these estimates suggests that reforms have moderate positive effects on the growth in employment per capita, but no systematic effect on any of the other outcome variables. This is consistent with the evidence that the UK reforms contributed to the country's improved employment record but raises some doubt about the impact of the reforms on productivity. The weakness of the cross country evidence means that the case for a linkage between market-oriented reform and productivity growth must rest on the kinds of UK-specific micro-level analyses conducted in Green and Haskell (2002), Conyon and Freeman (2002), and Pencavel (2002).

\section{Conclusion}

This paper has examined two main facets of recent British experience: the market-oreinted reforms that the UK undertook in the 1980s and 1990s; and the relative economic progress of the country compared to other advanced countries. The evidence shows that the UK made greater market reforms than most other advanced countries and that it arrested the nearly century-long trend pattern of decline relative to its historic competitors, Germany and France. It is difficult to link the reforms to the improved economic performance relative to these other countries, but at the minimum our analysis has shown the change in the UK economy cannot be readily explained by standard macro-economic changes in labor or capital. Related studies present some of the more micro-based evidence that we used to judge the 
contribution of the reforms, and examine some of the accompanying costs. Absent a unequivocal counterfactual of what would have happened had UK not proceeded with its reforms, we cannot definitively judge the market reforms, though weighing the diverse evidence, they do seem to have played a positive role in aggregate economic grow th. 


\section{Bibliography}

Ashenfelter, Orley, David Ashmore, Olivier Deschenes. 1999. Do Unemployment Insurance Recipients Actively Seek Work? Randomized Trials in Four U.S. States," NBER W6982 (Feb).

Atkinson, A.B. and I. Micklewright. 1999. "Unemployment Compensation and Labour Market Transitions: A Critical Review" Journal of Economic Literature no 4:1679-1727.

Bean, Charles, and Nicholas Crafts. 1996. "British Economic Grow th since 1945: Relative Economic Decline.... and Renaissance?" In Nicholas Crafts and Gianni Toniolo, eds., Economic Growth in Europe since 1945. (Cambridge: Cambridge University Press).

Bertola, Giuseppi. 1990. "Job Security, Employment and Wages,” European Economic Review 34: pp. 851-886.

Blanchard, Olivier J. 1997. "The Medium Run,” Brookings Papers on Economic Activity 2: 89-141.

Blanchflower, David and Richard Freeman. 1993. "Did the Thatcher Reforms Change British Labour Performance?" In CUP/National Institute of Economic and Social Research Conference Volume Is the British Labour Market Different? (London).

Blanchflower, David G. and Lisa M. Lynch. 1994. "Training at Work: A Comparison of U.S. and British Youths". In Lisa M. Lynch (ed) Training and the Private Sector. (Chicago: University of Chicago Press for NBER).

Broadberry, Stephen N. and Karin Wagner. 1996. "Human Capital and Productivity in Manufacturing During the Twentieth Century: Britain, Germany, and the United States". In Bart van Ark and Nicolas Crafts (eds). Quantitative Aspects of Post-war European Economic Growth. (Cambridge: Cambridge University Press).

Bruno, Michael and Jeffrey Sachs. 1985. Economics of Worldwide Stagflation.. (Cambridge MA: Harvard University Press).

Calmfors, Lars and John Driffil. 1988. "Bargaining Structure, Corporatism and Macroeconomic Performance". Economic Policy 6: 13-62.

Conyon, Martin J. And Richard B. Freeman. "Shared Modes of Compensation and Firm Performance: UK Evidence." In Richard Blundell, David Card, and Richard B. Freeman, editors, Seeking a Premier League Economy. (Chicago: University of Chicago Press for NBER), forthcoming, 2002.

Detroit News. 2000. "Global Automotive Report”(June 13) www.detnews.com/2000.

Djankov, Simeon, Rafael La Porta, Florencio Lopez-de-Silanes, and Andrei Shleifer. 2000. "The Regulation of Entry,” NBER W P \#7892 (September).

Farber, Henry S. and Bruce Western. 2000. "Round Up The Usual Suspects: The Decline of Unions in The Private Sector, 1973-1998.” Princeton University Industrial Relations Section Working Paper \#437 (April).

Federal Republic of Germany, Federal Statistical Office. 1998. Statistiches Jahrbuch. (Wiesbaden, Germany: Statistiches Bundesamt). 
Feinstein, Charles H. 1999. "Structural Change in the Developed Countries During the Twentieth Century". Oxford Review of Economic Policy 15 (Winter): 35-55.

Fraser Institute. 2001. Economic Freedom of The World 2001 Annual Report. www.fraserinstitute.ca.

Freeman, Richard B. 1998. "Spurts in Union Growth: Defining Moments and Social Processes" in The Defining Moment: The Great Depression and the American Economy in the Twentieth Century. Michael Bordo, Claudia Goldin, and Eugene White (editors). University of Chicago Press for NBER.

Green, Richard and Jonathan Haskell. "Seeking a Premier League Economy: the Role of Privatisation." In Richard Blundell, David Card, and Richard B. Freeman, editors, Seeking a Premier League Economy. (Chicago: University of Chicago Press for NBER), forthcoming, 2002.

Griliches, Zvi. 1970. "Notes on the Role of Education in Production Functions and Growth Accounting". In W. Lee Hansen, ed., Education, Income and Human Capital. (New York: Columbia University Press).

Grout, Paul A.. 1984. "Investment and Wages in the Absence of Binding Contracts: A Nash Bargaining Approach," Econometrica 52 (March): 449-460.

Grubb, David, and William Wells. 1993. "Employment Regulation and Patterns of Work in EC Countries", OECD Economic Studies 21: 7-58.

Gwartney, James and Robert Lawson (with Dexter Samida). 2000. Economic Freedom of the World, 2000 Annual Report (Vancouver, British Columbia Canada: The Fraser Institute).

Hanke, Steve and Stephen Walters. 1997. "Economic Freedom, Prosperity, and Equality: A Survey" The Cato Journal 17:2 (Fall).

Harvard Center for International Development. 2000. The Global Competitiveness Report 2000. (Geneva: World Economic Forum)

Hicks, Stephen. 2000. "Trade Union Membership 1989-99: An Analysis of Data from the Certification Officer and Labour Force Survey". Labour Market Trends (July): 329-340.

Hoynes, Hilary and Richard Blundell. "Has 'In Work' Benefit Reform Helped the Labour Market?" ' In Richard Blundell, David Card, and Richard B. Freeman, editors, Seeking a Premier League Economy. (Chicago: University of Chicago Press for NBER), forthcoming, 2002.

La Porta, Rafael, Florencio Lopez-de-Silanes, Andrei Shleifer, and Robert Vishny. 1999. "Investor Protection and Corporate Valuation," NBER Working Paper \#7403 (October).

La Porta, Rafael, Florencio Lopez-de-Silanes, Andrei Shleifer, and Robert Vishny. 1997. "Legal

Determinants of External Finance," NBER W orking Paper \#5879 (January).

Lazear Edward P. 1990. "Job Security Provisions and Employment," Quarterly Journal of Economics 105 (August): 699-726.

Machin, Stephen, Mark Stewart, and John van Reenan.. 1993. "Multiple Unionism, Fragmented Bargaining and Economic Outcomes in Unionized U.K. Establishments," in David Metcalf and Simon 
Milner (eds.) New Perspectives on Industrial Disputes (London: Routledge).

Metcalf, David. 1994. "Transformation of British Industrial Relations? Institutions, Conduct, and Outcomes," In Ray Burrell (ed) The UK Labour Market: Comparative Aspects and Institutional Developments. (Cambridge: Cambridge University Press).

Millward, Neil, Alex Bryson, and John Forth. 2000. All Change at Work?: British employment relations 1980-98. (NY, Routledge).

Nicoletti, Giuseppe, Stefano Scarpetta and Olivier Boylaud. 2000. "Summary Indicators of Product Market Regulation with an Extension to Employment Protection Legislation," OECD Economic Department Working Paper Number 226, (ECO/WKP(99)18) (April).

O’Mahony, Mary. 1996. "Measures of Fixed Capital Stocks in the Post-war Period: A Five Country Study". In Bart van Ark and Nicolas Crafts (eds), Quantitative Aspects of Post-war European Economic Growth. (Cambridge: Cambridge University Press).

Organization for Economic Cooperation and Development (OECD). 1999. "Cross-Country Patterns of Product Market Regulation”. OECD Economic Outlook 66. Paris: OECD.

Organization for Economic Cooperation and Development (OECD). 1999. OECD Historical Statistics. (Paris: OECD).

Organization for Economic Cooperation and Development (OECD). 1998. Labor Force Statistics, 19771997. Paris: OECD.

Organization for Economic Cooperation and Development (OECD). 1995. Main Economic Indicators: Historical Statistics 1960-1994. Paris: OECD.

Organization for Economic Cooperation and Development (OECD). 1997. OECD Employment Outlook.

Organization for Economic Cooperation and Development (OECD). 1994. OECD Jobs Study. Paris: OECD.

Pencavel, John. forthcoming, this volume 2002. "The Surprising Retreat of Union Britain”. In Richard Blundell, David Card, and Richard Freeman (eds.) Seeking a Premier League Economy. (Chicago: University of Chicago Press for NBER, CEP, IFS).

Rabushka, Alvin. 2000. “The Director's Column,” Institute for Advanced Strategic and Policy Studies Quarterly Report (Winter). www.israeleconomy.org/quarterly/winter00/rebushka.htm.

Schmitt, John. 1995. "The Changing Structure of Male Earnings in Britain, 1974-1988," in Richard B. Freem an and Lawrence F. Katz (eds.) Differences and Changes in Wage Structures. (Chicago: University of Chicago Press for NBER).

United Kingdom Office of National Statistics. 1997. Economic Trends. Annual Supplement 1997.

London: The Stationery Office..

United States Department of Commerce, Bureau of the Census. Various years. March Current Population Survey. (Washington, DC: Data User Services Division). 
United States Department of Labor. 2000a. Bureau of Labor Statistics. "Comparative Real Gross Domestic Product Per Capita and Per E5mployed Person for Fourteen Countries, 1960-1998. Washington DC: USDOL Bureau of Labor Statistics Office of Productivity and Technology (March).

United States Department of Labor. 2000b. Bureau of Labor Statistics. "Comparative Civilian Labor Force Statistics for Ten Countries, 1959-1999. Washington DC: USDOL Bureau of Labor Statistics Office of Productivity and Technology (April).

van Ark, Bart. 1996. "Sectoral Growth Accounting and Structural Change in Post-war Europe". In Bart van Ark and Nicolas Crafts, eds., Quantitative Aspects of Post-war European Economic Growth. (Cambridge: Cambridge University Press).

Van Reenan, John. “Active Labour Market Policies: The British New Deal for the Young Unemployed in Context." "In Richard Blundell, David Card, and Richard B. Freeman, editors, Seeking a Premier League Economy. (Chicago: University of Chicago Press for NBER), forthcoming, 2002. 
Table 1: Fraser Institute Economic Freedom Ratings:

the UK and other Advanced OECD Economies in 1970-1999

\begin{tabular}{lcccccccc}
\hline & & & & & & & & Change \\
& 1970 & 1975 & 1980 & 1985 & 1990 & 1995 & 1999 & $1980-1999$ \\
& & & & & & & & \\
& & & & & & & & \\
United Kingd om & $\mathbf{6 4}$ & $\mathbf{6 3}$ & $\mathbf{6 6}$ & $\mathbf{7 9}$ & $\mathbf{8 4}$ & $\mathbf{8 7}$ & $\mathbf{8 8}$ & $\mathbf{2 2}$ \\
[Rank out of 22] & {$[19]$} & {$[13]$} & {$[15]$} & {$[5]$} & {$[2]$} & {$[2]$} & {$[2]$} & {$[2]$} \\
& & & & & & & & \\
Major Comparisons: & & & & & & & & 3 \\
Germany & 80 & 73 & 77 & 77 & 81 & 80 & 80 & 3 \\
France & 72 & 60 & 63 & 63 & 76 & 79 & 75 & 3 \\
US & 77 & 80 & 84 & 85 & 88 & 87 & 87 &
\end{tabular}

Other Developed Countries:

\begin{tabular}{lllllllll} 
Australia & 80 & 65 & 74 & 78 & 80 & 84 & 85 & 11 \\
Austria & 71 & 60 & 67 & 67 & 74 & 76 & 80 & 13 \\
Belgium & 91 & 75 & 78 & 79 & 80 & 82 & 79 & 1 \\
Canada & 80 & 73 & 79 & 81 & 84 & 80 & 82 & 3 \\
Denmark & 72 & 63 & 65 & 67 & 77 & 80 & 80 & 15 \\
Finland & 77 & 62 & 69 & 72 & 76 & 79 & 81 & 12 \\
Greece & 63 & 58 & 57 & 52 & 61 & 72 & 73 & 16 \\
Ireland & 68 & 61 & 66 & 67 & 73 & 86 & 85 & 19 \\
Italy & 68 & 54 & 56 & 59 & 72 & 72 & 78 & 22 \\
Japan & 73 & 69 & 75 & 76 & 81 & 81 & 79 & 4 \\
Luxembourg & 91 & 91 & 89 & 92 & 82 & 83 & 84 & -5 \\
Netherlands & 85 & 71 & 78 & 79 & 82 & 84 & 84 & 6 \\
New Zealand & 69 & 56 & 64 & 63 & 80 & 90 & 89 & 25 \\
Norway & 69 & 57 & 60 & 67 & 76 & 79 & 78 & 18 \\
Portugal & 58 & 33 & 56 & 56 & 64 & 79 & 78 & 22 \\
Spain & 67 & 59 & 61 & 63 & 69 & 80 & 76 & 14 \\
Sweden & 57 & 56 & 61 & 67 & 73 & 79 & 79 & 18 \\
Switzerland & 88 & 79 & 83 & 86 & 84 & 83 & 85 & 2 \\
\hline & & & & & & & &
\end{tabular}

Notes: A higher score denotes a more favorable ranking. In several cases, the UK is tied with one or more other countries at the particular rank.

Source: Data from Fraser Institute, Economic Freedom of The World 2001 Annual Report web-site www.fraserinstitute.ca.. The figures in this edition differ somewhat from those in earlier editions, as the Fraser Institute updated its estimates for earlier years, as well as adding 1999 data. 
Table 2: Indicators of Freedom in Markets in UK and other Advanced Economies 1980-1999

\begin{tabular}{|c|c|c|c|c|c|c|c|c|c|}
\hline & \multicolumn{2}{|c|}{$\begin{array}{c}\text { Structure of } \\
\text { Economy and } \\
\text { Use of Markets }\end{array}$} & \multicolumn{2}{|c|}{$\begin{array}{l}\text { Legal Structure/ } \\
\text { Property Rights }\end{array}$} & \multicolumn{2}{|c|}{$\begin{array}{l}\text { Freedom in Capital } \\
\text { Financial Markets }\end{array}$} & \multicolumn{3}{|c|}{ Unweighted Average* } \\
\hline & 1980 & 1999 & 1980 & 1999 & 1980 & 1999 & 1980 & 1999 & Change \\
\hline $\mathbf{U K}$ & 33 & 77 & 82 & 99 & 81 & 100 & 65 & 92 & 27 \\
\hline $\begin{array}{l}\text { [Rank out } \\
\text { of 22] }\end{array}$ & {$[13]$} & {$[3]$} & {$[14]$} & {$[1]$} & {$[7]$} & {$[1]$} & [9] & [3] & {$[4]$} \\
\hline \multicolumn{10}{|c|}{ Major Comparisons: } \\
\hline Germany & 43 & 49 & 91 & 99 & 76 & 81 & 70 & 76 & 6 \\
\hline France & 35 & 47 & 79 & 86 & 71 & 81 & 62 & 71 & 9 \\
\hline US & 53 & 81 & 100 & 98 & 92 & 93 & 82 & 91 & 9 \\
\hline
\end{tabular}

Other Developed Countries:

\begin{tabular}{lccccccccc} 
Australia & 50 & 66 & 85 & 98 & 67 & 93 & 67 & 86 & 19 \\
Austria & 24 & 53 & 96 & 99 & 55 & 85 & 58 & 79 & 21 \\
Belgium & 33 & 51 & 93 & 87 & 91 & 91 & 72 & 76 & 4 \\
Canada & 60 & 79 & 84 & 96 & 93 & 92 & 79 & 89 & 10 \\
Denmark & 33 & 51 & 84 & 99 & 83 & 98 & 67 & 83 & 16 \\
Finland & 42 & 57 & 79 & 100 & 68 & 87 & 63 & 81 & 18 \\
Greece & 21 & 49 & 62 & 58 & 35 & 73 & 39 & 60 & 21 \\
Ireland & 51 & 79 & 82 & 97 & 67 & 83 & 67 & 86 & 19 \\
Italy & 21 & 50 & 63 & 90 & 50 & 82 & 45 & 74 & 29 \\
Japan & 53 & 54 & 94 & 94 & 62 & 73 & 70 & 74 & 4 \\
Luxembourg & - & 68 & 100 & 100 & 100 & 92 & - & - & - \\
Netherlands & 41 & 73 & 88 & 99 & 91 & 96 & 73 & 89 & 16 \\
New Zealand & 37 & 92 & 96 & 98 & 58 & 93 & 64 & 94 & 30 \\
Norway & 21 & 55 & 82 & 96 & 59 & 88 & 48 & 80 & 32 \\
Portugal & 10 & 55 & 95 & 81 & 35 & 80 & 47 & 72 & 25 \\
Spain & 25 & 46 & 72 & 75 & 67 & 85 & 55 & 69 & 14 \\
Sweden & 24 & 57 & 76 & 95 & 61 & 87 & 54 & 80 & 26 \\
Switzerland & 72 & 74 & 97 & 98 & 75 & 85 & 81 & 86 & 5 \\
& & & & & & & & & \\
\hline
\end{tabular}

Notes: A higher score denotes a more favorable ranking. Source: Fraser Institute, Economic Freedom of The World 2001 Annual Report.

* The three indices that we have selected are weighted in the Fraser Index as follows:

(II) Structure of the Economy and Use of Markets (14.2\%); (V) Legal Structure and Property Rights (16.6\%); (VII) Freedom of Exchange in Capital and Financial Markets (17.2\%). Thus, they make up approximately half of the overall index. Their weights are sufficiently similar that our treating the three equally does not produce markedly different results than if we had used the Institutes's weighting scheme. 
Table 3: Rank of UK and Other Advanced Countries in Economic Competitiveness 2000

\begin{tabular}{|c|c|c|c|c|c|c|}
\hline & \multicolumn{6}{|c|}{ Selected Sub-Indices } \\
\hline & \multirow[t]{2}{*}{ Growth } & \multirow[t]{2}{*}{ Current } & \multicolumn{2}{|c|}{ Market Freedoms } & \multicolumn{2}{|c|}{ Public Capital } \\
\hline & & & $\begin{array}{c}\text { Govt } \\
\text { Bureaucracy }\end{array}$ & $\begin{array}{l}\text { Property } \\
\text { Rights }\end{array}$ & Infrastructure & Schools \\
\hline & (1) & $(2)$ & (3) & (4) & $(5)$ & $(6)$ \\
\hline UK & 7 & 8 & 2 & 6 & 17 & 20 \\
\hline France & 18 & 14 & 13 & 7 & 2 & 8 \\
\hline Germany & 12 & 3 & 19 & 14 & 7 & 11 \\
\hline US & 1 & 2 & 14 & 9 & 6 & 18 \\
\hline Australia & 9 & 9 & 11 & 8 & 12 & 9 \\
\hline Austria & 15 & 12 & 17 & 5 & 8 & 1 \\
\hline Belgium & 14 & 11 & 19 & 11 & 14 & 6 \\
\hline Canada & 6 & 10 & 12 & 15 & 9 & 12 \\
\hline Denmark & 11 & 6 & 8 & 3 & 4 & 10 \\
\hline Finland & 5 & 1 & 1 & 2 & 1 & 3 \\
\hline Greece & 21 & 21 & 21 & 21 & 21 & 22 \\
\hline Ireland & 4 & 17 & 16 & 13 & 22 & 4 \\
\hline Italy & 22 & 19 & 22 & 22 & 20 & 17 \\
\hline Japan & 17 & 13 & 5 & 19 & 13 & 13 \\
\hline Luxembourg & 2 & -- & 3 & 1 & 5 & 2 \\
\hline Netherlands & 3 & 4 & 15 & 4 & 11 & 7 \\
\hline New Zealand & 16 & 15 & 6 & 10 & 15 & 14 \\
\hline Norway & 13 & 16 & 7 & 16 & 16 & 15 \\
\hline Portugal & 19 & 20 & 20 & 20 & 19 & 21 \\
\hline Spain & 20 & 18 & 18 & 17 & 18 & 19 \\
\hline Sweden & 10 & 7 & 9 & 18 & 10 & 16 \\
\hline Switzerland & 8 & 5 & 4 & 12 & 3 & 5 \\
\hline
\end{tabular}

SOURCE: World Economic Forum / Harvard Center for International Development, The Global Competitiveness Report 2000: (1) growth competitiveness ranking, Table 1; (2) current competitiveness index ranking, Table 2; (3) time with government bureaucracy, p. 246; (4) Protection of property rights (property rights are clearly delineated and protected by the law) p. 240; (5) Overall infrastructure (the quality of the infrastructure is among the best in the world) p. 256; (6) public-funded schools (the public schools are of high quality) p. 268. 
Table 4: Country Regulatory Policies of UK and other Advanced Economies, Indices from OECD 1998 Regulatory Data Base

\begin{tabular}{|c|c|c|c|c|c|c|c|}
\hline & & ard Orientec & Regulatic & ons: & & Outward-oriented & \\
\hline & & Barriers to & & & & Regulations: & \\
\hline & State & Entrepre- & Admin. & Econ. & & Barriers to & TOTAL PRODUCT \\
\hline & Control & neurship & Regs. & Regs. & TOTAL & Trade/Invest. & MARKET REGS. \\
\hline & (1) & (2) & (3) & (4) & (5) & (6) & (7) \\
\hline UK & 55 & 48 & 50 & 60 & 50 & 43 & 50 \\
\hline [Rank out & {$[1]$} & {$[1]$} & {$[1]$} & [1] & {$[1]$} & {$[1]$} & {$[1]$} \\
\hline Of 21] & & & & & & & \\
\hline Major Compe & titors: & & & & & & \\
\hline Germany & 176 & 210 & 270 & 140 & 190 & 54 & 140 \\
\hline France & 263 & 273 & 310 & 230 & 270 & 103 & 210 \\
\hline US & 85 & 126 & 70 & 100 & 110 & 87 & 100 \\
\hline Ireland & 94 & 120 & 150 & 80 & 80 & 43 & 80 \\
\hline Other Develof & ped Cou & & & & & & \\
\hline Australia & 126 & 113 & 110 & 130 & 120 & 43 & 90 \\
\hline Austria & 211 & 160 & 160 & 210 & 118 & 54 & 140 \\
\hline Belgium & 278 & 255 & 300 & 240 & 270 & 63 & 190 \\
\hline Canada & 129 & 80 & 90 & 110 & 100 & 215 & 150 \\
\hline Denmark & 246 & 132 & 110 & 230 & 190 & 54 & 140 \\
\hline Finland & 268 & 193 & 220 & 210 & 230 & 63 & 170 \\
\hline Greece & 387 & 166 & 200 & 310 & 270 & 132 & 220 \\
\hline Italy & 392 & 274 & 300 & 350 & 330 & 49 & 230 \\
\hline Japan & 129 & 233 & 270 & 140 & 180 & 102 & 150 \\
\hline Nether & 228 & 141 & 150 & 210 & 180 & 54 & 140 \\
\hline Norway & 319 & 133 & 140 & 270 & 220 & 215 & 220 \\
\hline New Zealand & 166 & 121 & 150 & 140 & 140 & 95 & 130 \\
\hline Portugal & 283 & 146 & 150 & 250 & 210 & 107 & 170 \\
\hline Spain & 259 & 177 & 230 & 210 & 220 & 68 & 160 \\
\hline Sweden & 151 & 180 & 200 & 130 & 170 & 84 & 140 \\
\hline Switzerland & 208 & 224 & 260 & 190 & 220 & 132 & 180 \\
\hline
\end{tabular}

Notes: A higher score indicates more burdensome or complex regulations. Source: Nicoletti, Scarpetta, and Boylaud, 1999. Data on state control (column 1) from Table A3-1. Data on barriers to entrepreneurship (column 2) from Table A3-2. Data on administrative regulations (column 3) from Table A3-4. Data on economic regulations (column 4) from Table A3-5. Data on total inward oriented policies (column 5) from Table A3-6. Data on barriers to trade and foreign investment (column 6) from Table A3-3. Data on total product market regulations (column 7) from Table A3-7. 
Table 5: Ranking of Advanced Countries

in Centralization/Decentralization in Wage Setting (Higher=More Centralized)

\begin{tabular}{|c|c|c|c|c|c|c|c|c|c|c|c|}
\hline & \multicolumn{10}{|c|}{ Late } & \multirow{3}{*}{$\begin{array}{l}\text { Change } \\
1980 \text { s to } \\
1990 \mathrm{~s} \\
\text { (coded 1-3) }\end{array}$} \\
\hline & \multicolumn{2}{|c|}{$\underline{\text { Early } 1980 \mathrm{~s}}$} & \multicolumn{4}{|c|}{ Mid 1980s } & \multirow{2}{*}{$\begin{array}{l}1980 \mathrm{~s} \\
1988\end{array}$} & \multicolumn{3}{|c|}{$1990 \mathrm{~s}$} & \\
\hline & 1979 & 1981 & 1984 & 1984 & 1986 & 1986 & & 1990 & 1991 & 1995 & \\
\hline Australia & 10 & - & 9 & 3 & 3 & 10 & 8 & - & 4 & 7 & $2,1988+, 1$ \\
\hline Austria & 16 & 15 & 16 & 15 & 17 & 16 & 17 & 10 & 18 & 17 & 3 \\
\hline Belgium & 8 & 9 & 15 & 10 & 9 & 6 & 10 & - & 10 & 11 & 2 \\
\hline Canada & 1 & 5 & 5 & 3 & 2 & 5 & 1 & - & 2 & 3 & 1 \\
\hline Denmark & 13 & 12 & 13 & 10 & 11 & 12 & 14 & - & 14 & 17 & 3 \\
\hline Finland & 12 & 12 & 14 & 10 & 10 & 8 & 13 & - & 11 & 17 & $3->2$ \\
\hline France & 5 & 3 & 2 & 18 & 5 & 3 & 7 & 3 & 7 & 11 & 2 \\
\hline Germany & 9 & 8 & 11 & 10 & 16 & 15 & 12 & 6 & 12 & 14 & 3 \\
\hline Italy & 3 & 1 & 6 & 6 & 4 & 1 & 5 & 4 & 6 & 7 & $1,1992+, 3$ \\
\hline Japan & 6 & - & 3 & 18 & 8 & 14 & 4 & 11 & 9 & 11 & 1 \\
\hline Netherlands & 7 & 10 & 12 & 15 & 15 & 9 & 11 & 5 & 15 & 11 & $2,1988+, 3$ \\
\hline New Zealand & 11 & - & - & 3 & 7 & 4 & 9 & - & 3 & 3 & $2,1991+, 1$ \\
\hline Norway & 15 & 14 & 17 & 17 & 13 & 11 & 16 & 8 & 17 & 17 & 3 \\
\hline Portugal & - & - & - & - & - & - & - & - & - & - & 2 \\
\hline Spain & - & - & 1 & - & - & - & - & - & - & 7 & $3,1985+, 2$ \\
\hline Sweden & 14 & 12 & 18 & 15 & 13 & 13 & 15 & 7 & 16 & 17 & $3->2$ \\
\hline Switzerland & - & 7 & 7 & 10 & 12 & - & 3 & 9 & 13 & 11 & - \\
\hline UK & 4 & 2 & 10 & 6 & 6 & 2 & 6 & 2 & 5 & 3 & $2->1$ \\
\hline US & 2 & 5 & 4 & 3 & 1 & 7 & 2 & 1 & 1 & 3 & 1 \\
\hline
\end{tabular}

Source: OECD Employment Outlook, July 1997, table 3.4. The columns are from the following studies included in the OECD Employment Outlook: 1979, Blyth; 1981, Schmitter; 1984 (first entry), Cameron; 1984 (second entry), Lehmbruch; 1986 (first entry), Bruno and Sachs; 1986 (second entry), Tarantelli; 1988, Calm fors/Driffil; 1990, Soskice; 1991, Lipjphart/Crepaz; 1991, Layard, Nickell, Jackman; 1995. The entry in the last column is from Elmeskov, Martin, Scarpetta, 1998. In cases where there is a single entry it refers to the entire period, with codes of 1 (decentralized wage setting) to 3 (centralized wage setting). In cases where there are two entries separated by a date, the first refers to the period before the date and the second to the period after. In cases where there are two entries with an arrow, the entries refer to a general trend. 
Table 6: Employment Protection Indices

\begin{tabular}{|c|c|c|c|c|}
\hline & \multirow{2}{*}{$\begin{array}{l}\text { Late } 1980 \mathrm{~s} \\
\qquad \mathrm{~A} \\
(1)\end{array}$} & \multicolumn{2}{|c|}{ Late $1990 \mathrm{~s}$} & \multirow{2}{*}{$\begin{array}{c}\text { Change } \\
\text { A } \\
(4)\end{array}$} \\
\hline & & $\begin{array}{l}A \\
(2)\end{array}$ & $\begin{array}{l}\mathrm{B} \\
(3)\end{array}$ & \\
\hline \multicolumn{5}{|l|}{ European Union } \\
\hline Austria & 2.2 & 2.2 & 2.3 & 0 \\
\hline Belgium & 3.1 & 2.1 & 2.5 & -1.0 \\
\hline Denmark & 2.1 & 1.2 & 1.5 & -0.9 \\
\hline Finland & 2.3 & 2.0 & 2.1 & -0.3 \\
\hline France & 2.7 & 3.0 & 2.8 & 0.3 \\
\hline Germany & 3.2 & 2.5 & 2.6 & -0.7 \\
\hline Greece & 3.6 & 3.6 & 3.5 & 0.0 \\
\hline Ireland & 0.9 & 0.9 & 1.1 & 0.0 \\
\hline Italy & 4.1 & 3.3 & 3.4 & -0.8 \\
\hline Netherlands & 2.7 & 2.1 & 2.1 & -0.6 \\
\hline Norway & 3.0 & 2.6 & 2.6 & -0.4 \\
\hline Portugal & 4.1 & 3.7 & 3.7 & -0.4 \\
\hline Spain & 3.7 & 3.1 & 3.1 & -0.6 \\
\hline Sweden & 3.5 & 2.2 & 2.6 & -1.3 \\
\hline Switzerland & 1.0 & 1.0 & 1.5 & 0.0 \\
\hline United Kingdom & 0.5 & 0.5 & 0.9 & 0.0 \\
\hline \multicolumn{5}{|l|}{ non-EU countries } \\
\hline Australia & 0.9 & 0.9 & 1.2 & 0.0 \\
\hline Canada & 0.6 & 0.6 & 1.1 & 0.0 \\
\hline Japan & - & 2.4 & 2.3 & -- \\
\hline New Zealand & - & 2.6 & 0.9 & -- \\
\hline US & 0.2 & 0.2 & 0.7 & 0.0 \\
\hline
\end{tabular}

Source: Columns, 1-3, OECD, Employment Outlook, 1999, table 2.5 Columns 1 and 2 use a measure of protection for regular and temporary contracts. Column 3 uses a more comprehensive measure that also includes collective dismissal legislation. Column 4 gives the difference between columns 1 and 2 . 
Table 7: Regulation of Business Formation and Protection of Investors in Advanced OECD Countries

\begin{tabular}{|c|c|c|c|c|c|c|}
\hline & \multicolumn{3}{|c|}{ Business Formation } & \multicolumn{3}{|c|}{ Protection of Investors (higher= better) } \\
\hline & $\begin{array}{l}\text { \# Procedures } \\
\text { required }\end{array}$ & $\begin{array}{c}\text { Days to get } \\
\text { Approval }\end{array}$ & $\begin{array}{l}\text { Cost/GDP } \\
\text { Per Capita }\end{array}$ & Rule of Law & $\begin{array}{l}\text { Anti-Director } \\
\text { Rights }\end{array}$ & $\begin{array}{c}\text { Creditor } \\
\text { Rights }\end{array}$ \\
\hline Australia & 3 & 3 & .0209 & 10 & 4 & 1 \\
\hline Austria & 12 & 154 & .4545 & 10 & 2 & 3 \\
\hline Belgium & 8 & 42 & .1001 & 10 & 0 & 2 \\
\hline Canada & 2 & 2 & .0140 & 10 & 4 & 1 \\
\hline Denmark & 5 & 21 & .0136 & 10 & 3 & 3 \\
\hline Finland & 4 & 32 & .0199 & 10 & 2 & 1 \\
\hline France & 16 & 66 & .1970 & 8.98 & 2 & 0 \\
\hline Germany & 7 & 90 & .0851 & 9.23 & 1 & 3 \\
\hline Greece & 13 & 53 & .4799 & 6.18 & 1 & 1 \\
\hline Ireland & 4 & 25 & .1145 & 7.80 & 3 & 1 \\
\hline Italy & 11 & 121 & .2474 & 8.33 & 0 & 2 \\
\hline Japan & 11 & 50 & .1144 & 8.98 & 3 & 2 \\
\hline Neth & 8 & 77 & .3031 & 10 & 2 & 2 \\
\hline N Zealand & 3 & 17 & .0042 & 10 & 4 & 3 \\
\hline Norway & 6 & 24 & .0249 & 10 & 3 & 2 \\
\hline Portugal & 12 & 99 & .3129 & 8.68 & 2 & 1 \\
\hline Spain & 11 & 83 & .1269 & 7.80 & 2 & 2 \\
\hline Sweden & 4 & 17 & .0254 & 10 & 2 & 2 \\
\hline Switz & 12 & 88 & .1336 & 10 & 1 & 1 \\
\hline UK & 7 & 11 & .0056 & 8.57 & 4 & 4 \\
\hline US & 4 & 7 & .0096 & 10 & 5 & 1 \\
\hline
\end{tabular}

Source: Djankov, La Porta, Lopez-de-Silanes and Shleifer, 2000; La Porta, Lopez-de-Silanes, Shleifer and Vishny, 1999; La Porta Lopez-de-Silanes, Shleifer and Vishny, 1997. The number of procedures entry is a count of the number of safety \& health, environment, taxation, labor, and screening procedures needed to legally start a new business. The time entry is an estimate of the number of days before a new firm can start operation. The cost entry is an estimate of the monetary time and direct cost of meeting requirements as fraction of GDP per capita in 1997. The rule of law entry is an index from the International Country Risk Guide. The anti-director rights entry is an index that measures shareholder rights (scaled from 0 to 5) while the creditor rights entry is an index of creditor rights (scaled from 0 to 4 ). 
Table 8: Real Gross Domestic Product Per Capita for Various Countries, 1960-1998

In 1998 U.S. Dollars Using PPP Exchange Rates

1960

1979
$9,974 \quad 15,202$

21,502

74

68

66

Major Competitors:

West Germany

$9,842 \quad 17,769 \quad 24,868$

France

8,546

17,064

22,255

United States

13,414

22,254

32,413

other countries:

Italy

Austria

7,666

15,817

23,930

Belgium

8,069

16,016

24,239

Denmark

9,793

16,807

26,176

$9,351 \quad 16,736$

24,008

8,120

16,244

27,581

$9,894 \quad 16,765$

21,218

4,672

14,812

24,170

Japan

Canada

10,503

19,099

25,496

UK Rank (out of 13)
1960
1979
1998

Relative to U.S. $=100$

Based on PPP Exchange Rates 
Table 9: Growth Rates in Real Gross Domestic per Capita and Its Components

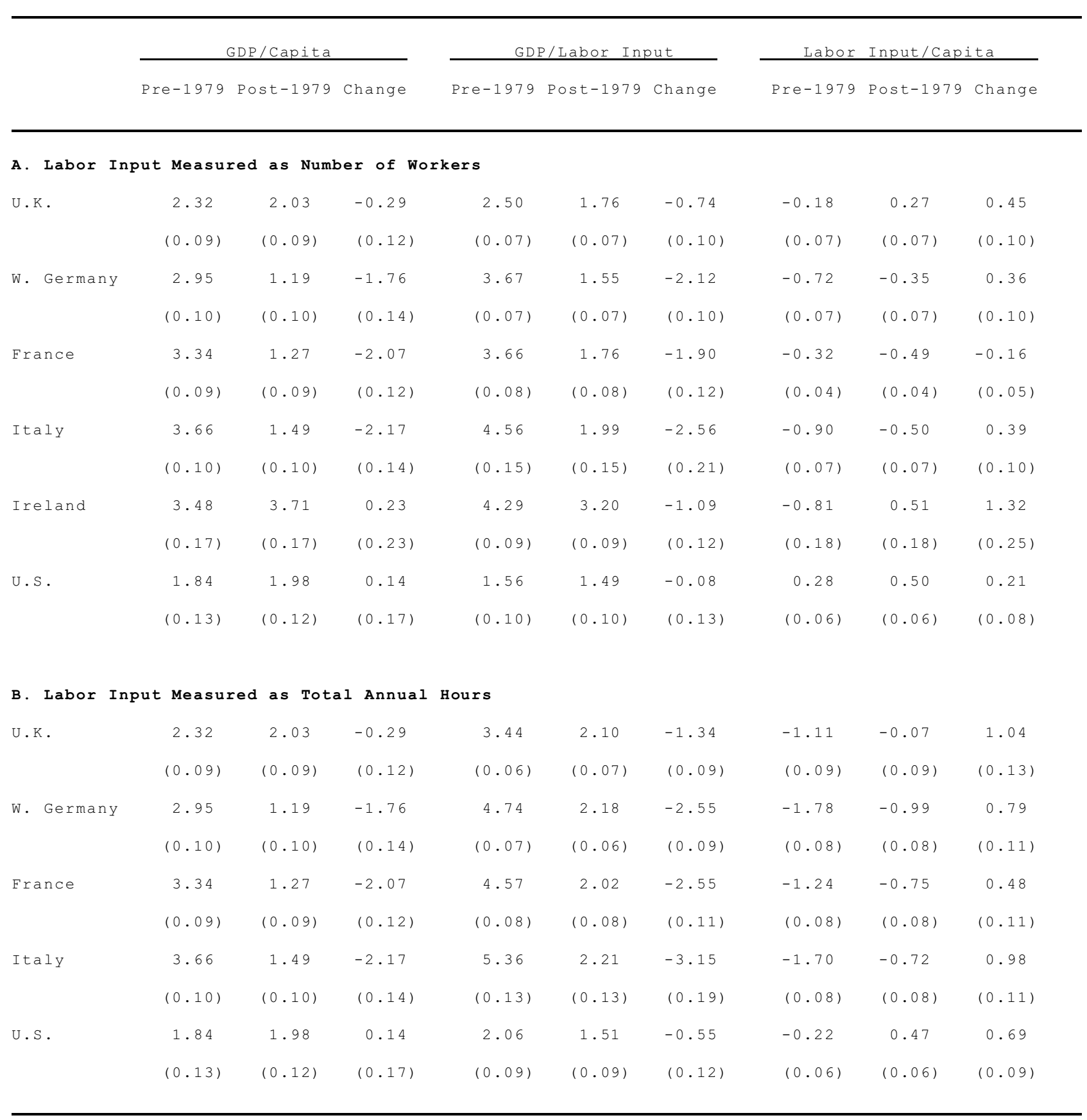

Notes: Coefficients (and standard errors in parentheses) obtained from linear regression models fit to annual data from 1960 to 1999. GDP per capita represents real GDP divided by total civilian working age population (age 15/16 or older). 
Table 10: Decomposition of Relative Growth Rates of GDP per Capita Between the United Kingdom and Other Countries

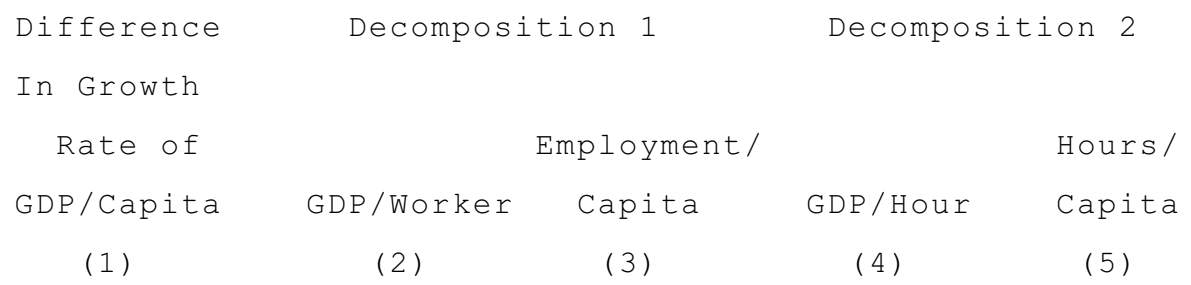

\begin{tabular}{|c|c|c|c|c|c|}
\hline United Kingdom & -0.63 & -1.17 & 0.54 & $-1 \cdot 30$ & 0.67 \\
\hline - West Germany & $(0.13)$ & $(0.11)$ & $(0.10)$ & $(0.09)$ & $(0.12)$ \\
\hline United Kingdom & -1.02 & -1.16 & 0.14 & -1.13 & 0.12 \\
\hline - France & $(0.13)$ & $(0.11)$ & $(0.08)$ & $(0.10)$ & $(0.12)$ \\
\hline United Kingdom & 0.48 & 0.94 & -0.46 & 1.38 & -0.89 \\
\hline - United States & $(0.16)$ & $(0.12)$ & $(0.08)$ & $(0.11)$ & $(0.11)$ \\
\hline B. $1979-1999$ & & & & & \\
\hline United Kingdom & 0.84 & 0.21 & 0.62 & -0.08 & 0.92 \\
\hline - West Germany & $(0.13)$ & $(0.10)$ & $(0.10)$ & $(0.09)$ & $(0.12)$ \\
\hline United Kingdom & 0.76 & 0.00 & 0.76 & 0.08 & 0.68 \\
\hline - Erance & $(0.13)$ & $(0.11)$ & $(0.08)$ & $(0.11)$ & $(0.12)$ \\
\hline United Kingdom & 0.05 & 0.27 & -0.23 & 0.59 & -0.54 \\
\hline - United States & $(0.15)$ & $(0.12)$ & $(0.09)$ & $(0.11)$ & $(0.11)$ \\
\hline
\end{tabular}

\section{Difference in Growth Rates: 1979-99 Compared to 1960-79}

\begin{tabular}{|c|c|c|c|c|c|}
\hline United Kingdom & 1.47 & 1.38 & 0.09 & 1.21 & 0.25 \\
\hline - West Germany & $(0.18)$ & $(0.14)$ & $(0.14)$ & $(0.13)$ & $(0.17)$ \\
\hline United Kingdom & 1.78 & 1.16 & 0.61 & 1.21 & 0.56 \\
\hline - France & $(0.17)$ & $(0.16)$ & $(0.11)$ & $(0.14)$ & $(0.17)$ \\
\hline United Kingdom & -0.43 & -0.66 & 0.24 & -0.79 & 0.35 \\
\hline - United States & $(0.21)$ & $(0.16)$ & $(0.13)$ & $(0.15)$ & $(0.16)$ \\
\hline
\end{tabular}

Notes: Entries in column 1 represent the difference in the estimated trend growth rate in GDP per capita between the UK and the comparison country. Decomposition 1 in columns 2 and 3 divides GDP per capita into GDP per employed worker and employment per capita. Decomposition 2 in columns 4 and 5 divides GDP per capita into GDP per hour worked, and hours per capita. Estimated standard errors in parentheses. 
Table 11: Contributions of Shift Out of Agriculture to Labor Productivity Trends

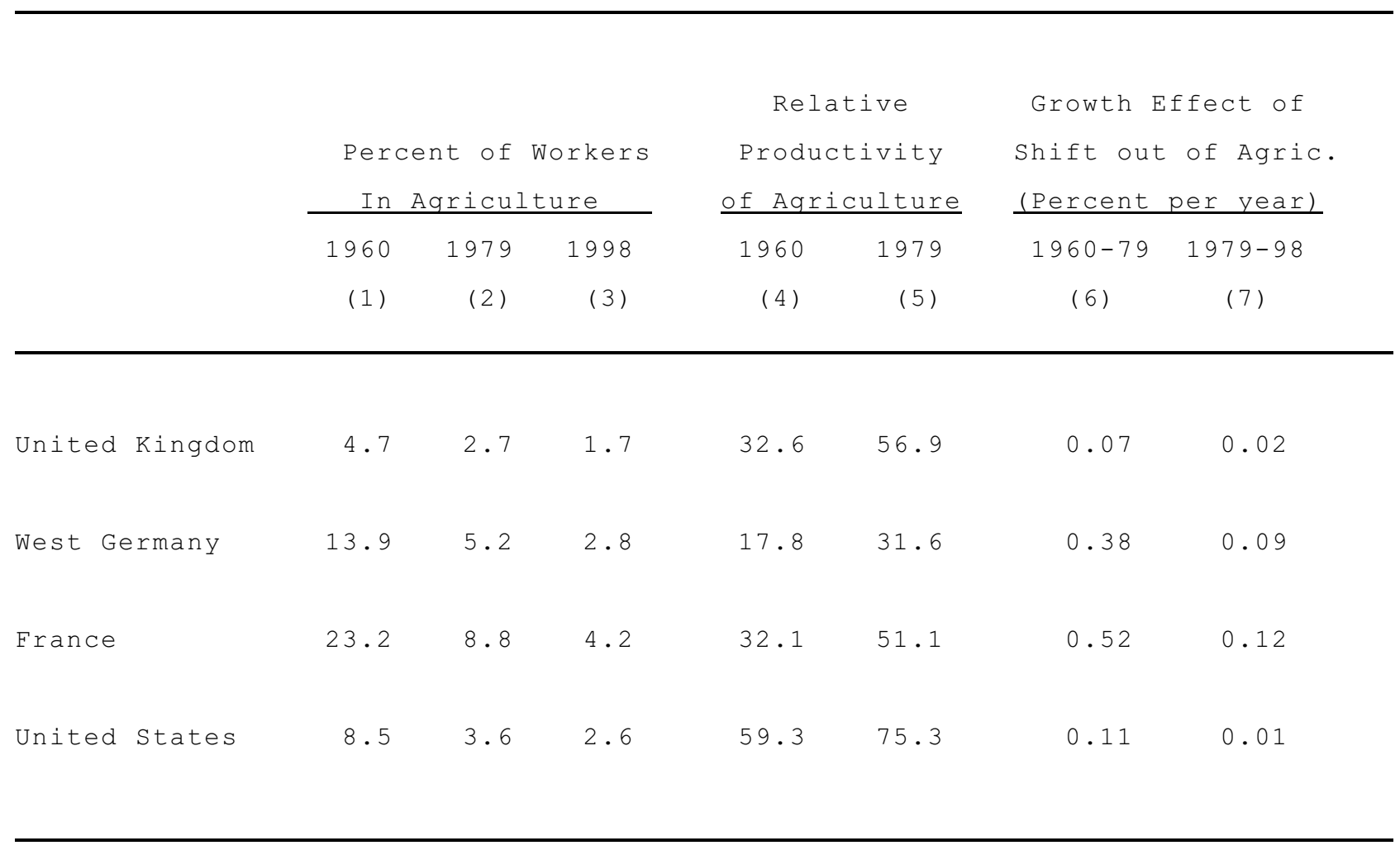

Notes: Entries in columns 1-3 represent the fraction of civilian employment in agriculture. Source: US BLS (2000b). The entries in columns 4 and 5 represent estimates of the value added per worker in agriculture relative to other sectors of the economy (in percent). Source: based on data reported in van Ark (1996, Appendix Tables 1 and 2). The entries in columns 6 and 7 represent share-shift estimates of the effect of the movement out of agricultural employment on the annul growth rate of labor productivity for the economy as a whole. 
Table 12: Contributions of Capital Accumulation to Relative Trends in Labor Productivity

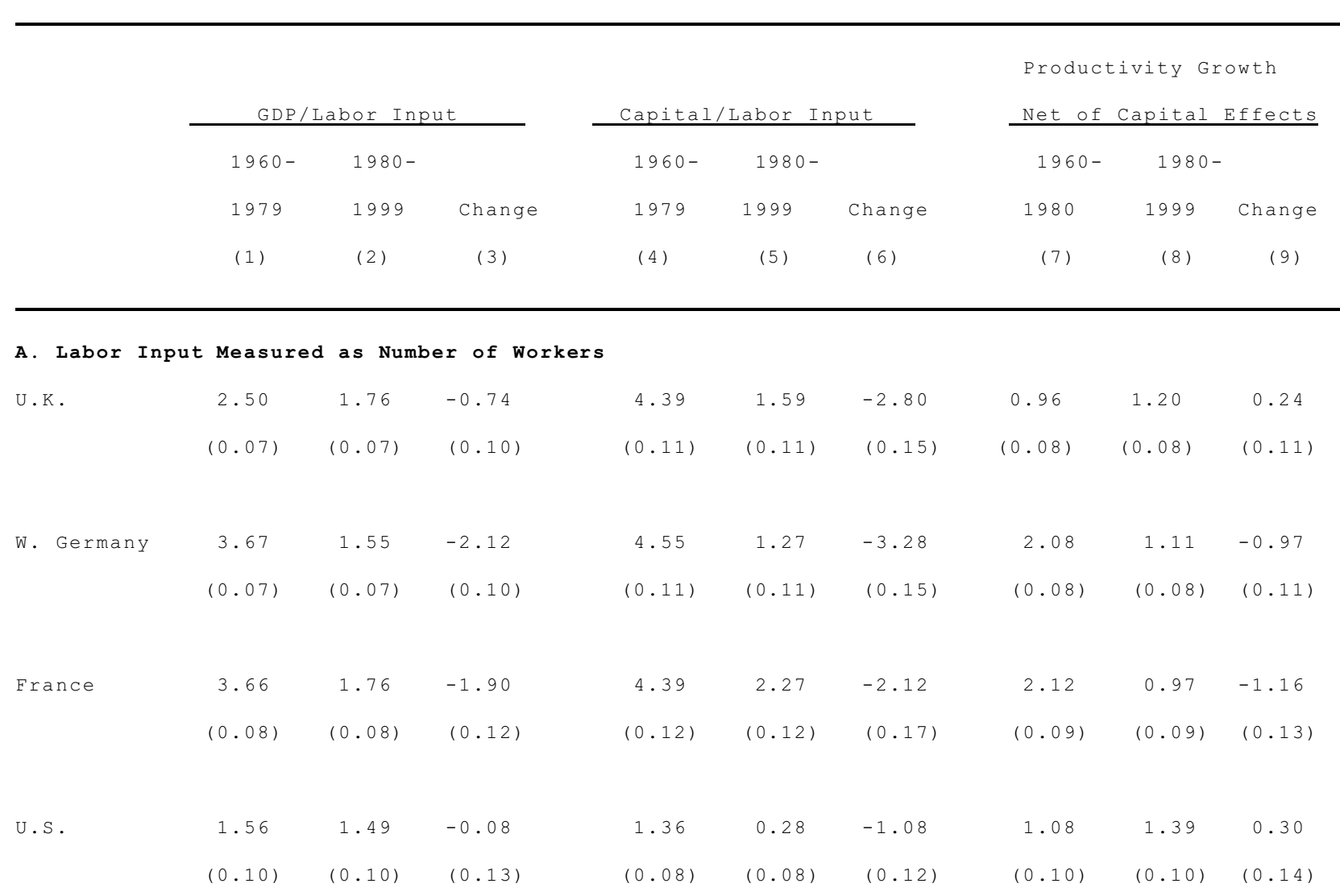

\section{B. Labor Input Measured as Total Annual Hours}

\begin{tabular}{|c|c|c|c|c|c|c|c|c|c|}
\hline \multirow[t]{2}{*}{ U. K. } & 3.44 & 2.10 & -1.34 & 5.33 & 1.93 & -3.40 & 1.57 & 1.42 & -0.15 \\
\hline & $(0.06)$ & $(0.07)$ & $(0.09)$ & $(0.12)$ & $(0.12)$ & $(0.17)$ & $(0.07)$ & $(0.08)$ & $(0.11)$ \\
\hline \multirow[t]{2}{*}{ W. Germany } & 4.74 & 2.18 & -2.55 & 5.61 & 1.90 & -3.71 & 2.78 & 1.52 & -1.25 \\
\hline & $(0.07)$ & $(0.06)$ & $(0.09)$ & $(0.11)$ & $(0.11)$ & $(0.16)$ & $(0.08)$ & $(0.07)$ & $(0.11)$ \\
\hline \multirow[t]{2}{*}{ France } & 4.57 & 2.02 & -2.55 & 5.30 & 2.54 & -2.76 & 2.72 & 1.13 & -1.58 \\
\hline & $(0.08)$ & $(0.08)$ & $(0.11)$ & $(0.15)$ & $(0.16)$ & $(0.22)$ & $(0.10)$ & $(0.10)$ & $(0.13)$ \\
\hline \multirow[t]{2}{*}{ U.S. } & 2.06 & 1.51 & -0.55 & 1.86 & 0.31 & -1.56 & 1.41 & 1.40 & -0.00 \\
\hline & $(0.09)$ & $(0.09)$ & $(0.12)$ & $(0.09)$ & $(0.09)$ & $(0.13)$ & $(0.10)$ & $(0.10)$ & $(0.13)$ \\
\hline
\end{tabular}

Notes: Standard errors in parentheses. Entries in columns 1-6 obtained from linear regression models fit to annual data from 1960 to 1999 for real GDP per unit of labor input, and real net capital per unit of labor input. Entries in columns 7-9 represent differences between growth rate of GDP per labor input, and 0.35 times the growth rate in capital per unit of labor input. See text equation (1). 
Table 13: Estimates of the Rate of Growth of Labor Quality

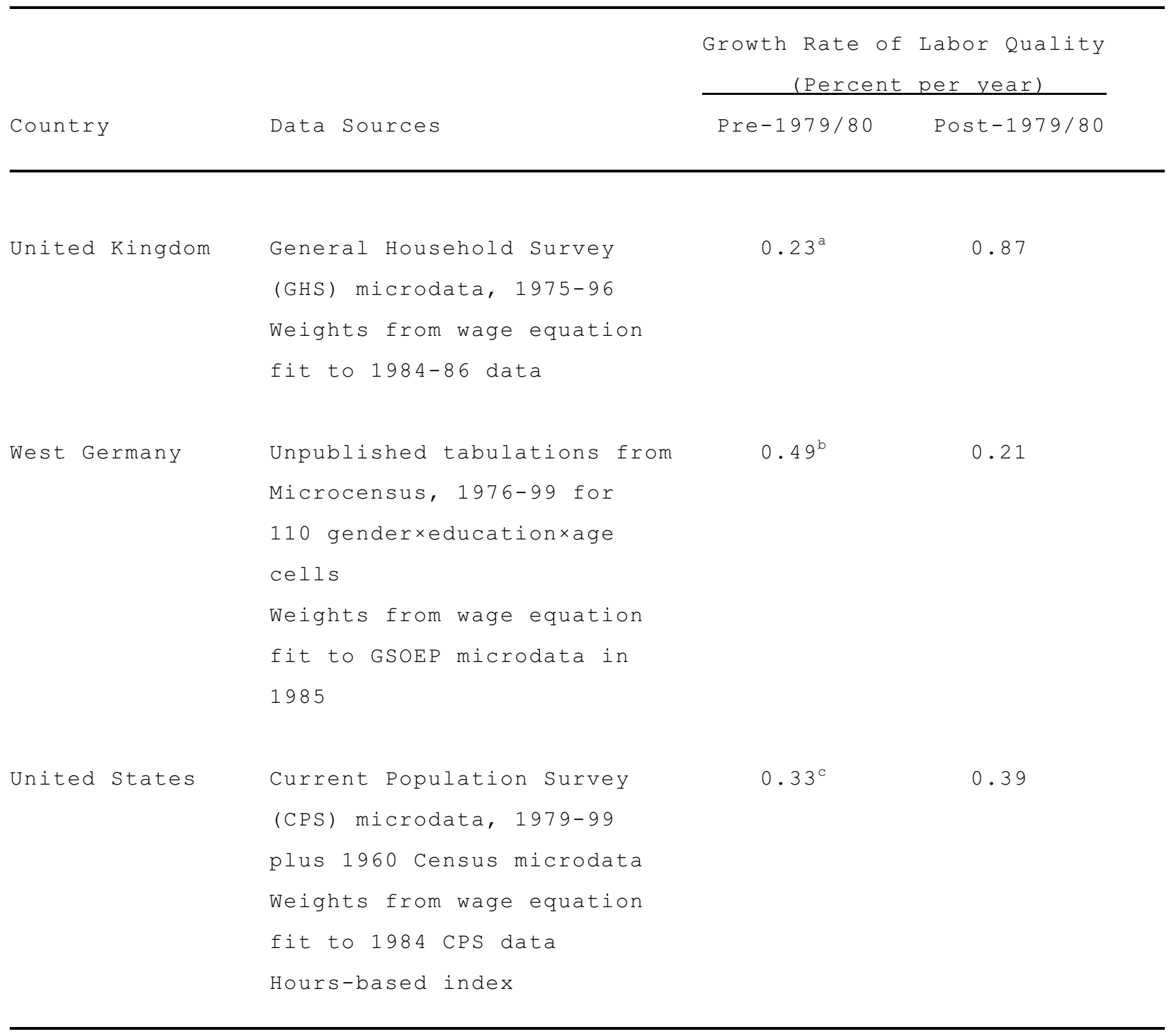

Notes: See text for description of method.

${ }^{a}$ Based on changes from 1975 to 1980 .

${ }^{b}$ Based on changes from 1976 to 1980 .

${ }^{c}$ Based on changes from 1959 to 1979 . 
Table 14: Summary of Contributions to Trends in Growth Rate of Labor Productivity per Hour Worked

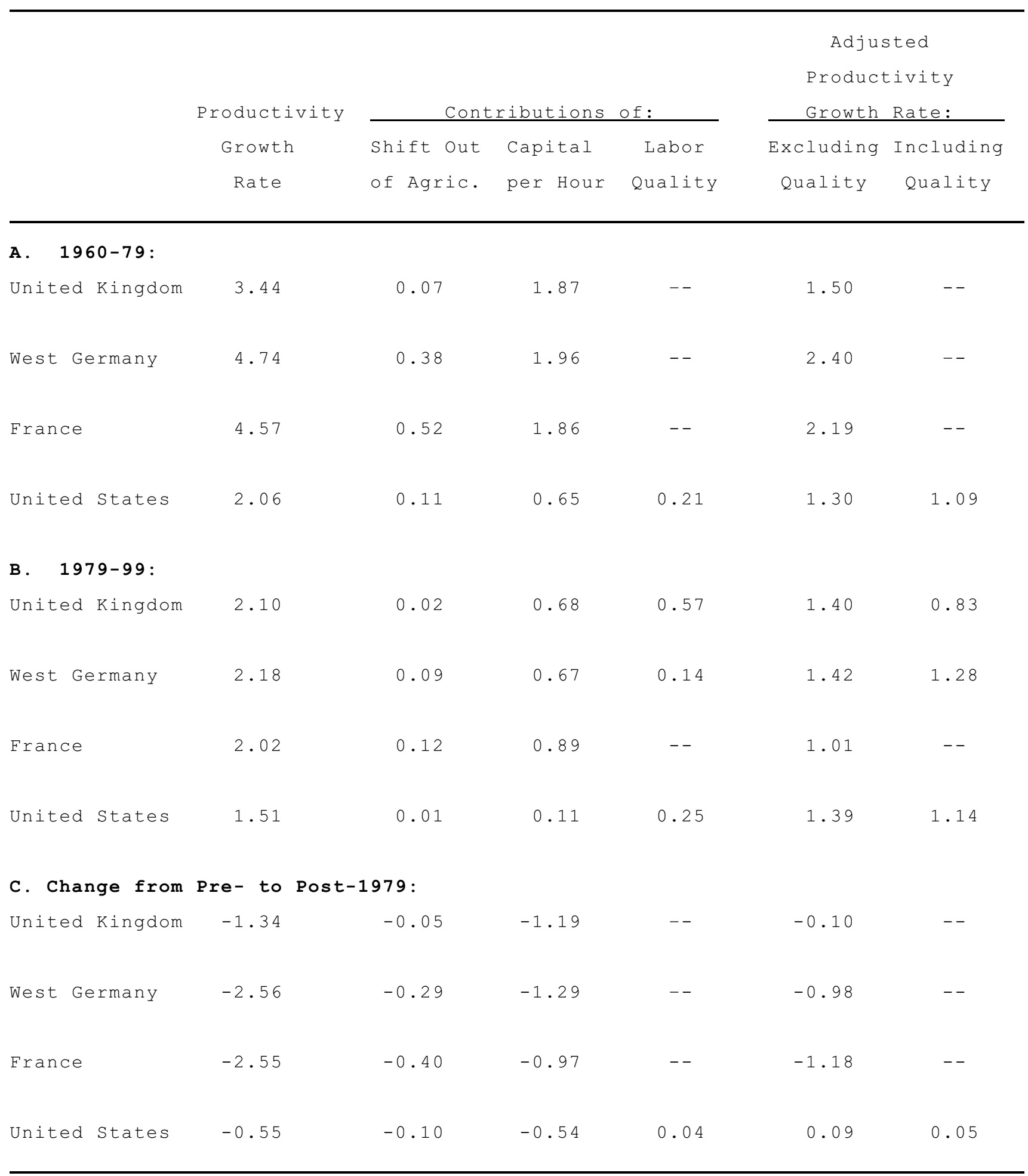

Sources: Productivity growth rates from Table 9. Contributions of shift out of agriculture from Table 11. Contributions of grow th in capital per hour estimated by multiplying trends in capital per hour in columns 4-5 of Table 12 by 0.35 . Contributions of labor quality obtained by multiplying entries in Table 13 by 0.65 . 
Table 15: Unemployment Benefit Replacement Ratios, 1960-95

\begin{tabular}{|c|c|c|c|c|}
\hline & $1965-72$ & 1973-79 & $1980-87$ & 1988-95 \\
\hline Australia & 0.15 & 0.23 & 0.23 & 0.26 \\
\hline Austria & 0.17 & 0.3 & 0.34 & 0.34 \\
\hline Belgium & 0.4 & 0.55 & 0.5 & 0.48 \\
\hline Canada & 0.43 & 0.59 & 0.57 & 0.58 \\
\hline Denmark & 0.35 & 0.55 & 0.67 & 0.64 \\
\hline Finland & 0.18 & 0.29 & 0.38 & 0.53 \\
\hline France & 0.51 & 0.56 & 0.61 & 0.58 \\
\hline West Germany & 0.41 & 0.39 & 0.38 & 0.37 \\
\hline Ireland & 0.24 & 0.44 & 0.5 & 0.4 \\
\hline Italy & 0.06 & 0.04 & 0.02 & 0.26 \\
\hline Japan & 0.38 & 0.31 & 0.29 & 0.3 \\
\hline Netherlands & 0.64 & 0.65 & 0.67 & 0.7 \\
\hline Norway & 0.13 & 0.28 & 0.56 & 0.62 \\
\hline New Zealand & 0.3 & 0.27 & 0.3 & 0.29 \\
\hline Portugal & - & 0.17 & 0.44 & 0.65 \\
\hline Spain & 0.48 & 0.62 & 0.75 & 0.68 \\
\hline Sweden & 0.16 & 0.57 & 0.7 & 0.72 \\
\hline Switzerland & 0.02 & 0.21 & 0.48 & 0.61 \\
\hline UK & 0.36 & 0.34 & 0.26 & 0.22 \\
\hline US & 0.23 & 0.28 & 0.3 & 0.26 \\
\hline
\end{tabular}

Source: OECD. Based on the replacement ratio in the first year of an unemployment spell averaged over three family types. 
Table 16: Coefficients and Standard Errors on the Fraser Index of Economic Freedom in Regressions of the level and In change in Macro-economic variables, OECD countries, 1970-1999

\begin{tabular}{|c|c|c|c|c|c|c|}
\hline \multirow[b]{2}{*}{ Dependent Variable } & \multirow[b]{2}{*}{ Line No. } & \multicolumn{2}{|c|}{ Fraser Institute Index } & \multirow{2}{*}{$\begin{array}{c}\text { Year } \\
\text { Dummies? }\end{array}$} & \multirow{2}{*}{$\begin{array}{l}\text { Country } \\
\text { Dummies? }\end{array}$} & \multirow[b]{2}{*}{ R-squared } \\
\hline & & Coefficient & Std Error & & & \\
\hline \multirow[t]{2}{*}{$\log$ GDP/Capita } & 1. & 0.144 & -0.017 & Yes & No & 0.593 \\
\hline & 2. & -0.001 & -0.016 & Yes & Yes & 0.929 \\
\hline \multirow[t]{2}{*}{$\Delta \log$ GDP/Capita } & 3. & -0.006 & -0.006 & Yes & No & 0.183 \\
\hline & 4. & 0.001 & -0.011 & Yes & Yes & 0.449 \\
\hline \multirow[t]{2}{*}{$\log$ GDP/Worker } & 5. & 0.332 & -0.149 & Yes & No & 0.053 \\
\hline & 6. & -0.001 & -0.015 & Yes & Yes & 0.998 \\
\hline \multirow[t]{2}{*}{$\Delta \log \mathrm{GDP} / \mathrm{W}$ orker } & 7. & -0.012 & -0.005 & Yes & No & 0.170 \\
\hline & 8. & -0.004 & -0.009 & Yes & Yes & 0.425 \\
\hline \multirow[t]{2}{*}{ log Employment/Pop. } & 9. & 1.349 & -0.759 & Yes & No & 0.044 \\
\hline & 10 & 0.351 & -0.606 & Yes & Yes & 0.87 \\
\hline \multirow[t]{2}{*}{$\Delta$ log Employment/Pop. } & 11. & 0.005 & -0.005 & Yes & No & 0.113 \\
\hline & 12. & 0.020 & -0.010 & Yes & Yes & 0.213 \\
\hline
\end{tabular}

Source: Calculated using OECD Historical Statistics (1999); and Fraser Institute Index data as reported in Table 1 . 
Appendix Table 1: Age Structure of the Population, 1960 and 1997

$\begin{array}{lcccccc} & \begin{array}{c}1960 \\ \text { Percent } \\ \text { Under 15 }\end{array} & \begin{array}{c}\text { Percent } \\ \text { Age 15+ }\end{array} & \begin{array}{c}\text { Percent } \\ \text { of 15+ } \\ \text { Over } 64\end{array} & \begin{array}{c}\text { Percent } \\ \text { Under 15 }\end{array} & \begin{array}{c}\text { Percent } \\ \text { Age 15+ }\end{array} & \begin{array}{c}\text { Percent } \\ \text { of 15+ } \\ \text { Over 64 }\end{array} \\ \text { United Kingdom } & 23.3 & 76.7 & 15.2 & 19.3 & 80.7 & 19.5 \\ \text { Germany } & 21.3 & 78.7 & 13.7 & 15.9 & 84.1 & 19.3 \\ \text { France } & 26.7 & 73.4 & 15.8 & 19.1 & 80.9 & 19.1 \\ \text { Italy } & 23.4 & 76.6 & 11.7 & 15.3 & 84.7 & 18.5 \\ \text { Ireland } & 30.5 & 69.5 & 15.7 & 23.1 & 76.9 & 14.8 \\ \text { United States } & 31 & 69 & 13.3 & 22.3 & 77.7 & 15.4\end{array}$

Note: Based on data in OECD Labour Force Statistics 1977-1997. 
Appendix Table 2: Employment-Population Rates and

Annual Hours per Capita, 1960-1999

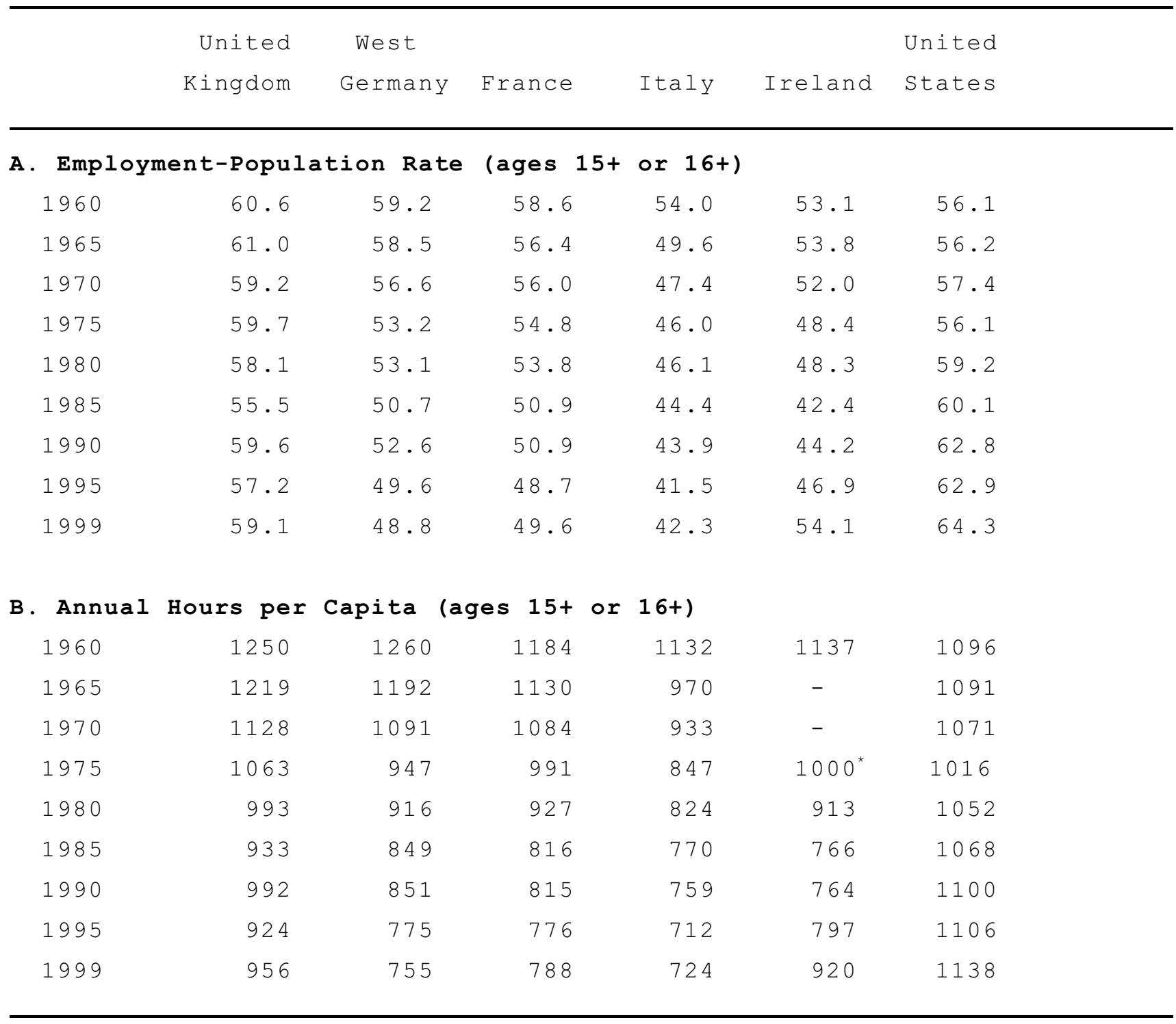

Notes: Employment and population data from BLS (2000). Population refers to the adult population (ages 16 and older in the US, ages 15-64 in other countries). Hours data for the U.K., Germany, France, and the U.S. are based on estimates of annual hours per worker from o'Mahoney (unpublished tables), updated using data from the OECD and the International Comparisons of output and Productivity (ICOP) project. Hours data for Italy are based on data from OECD. Hours data for Ireland are based on data from ICOP. 
Appendix Table 3: Employment Shares in Three Major Sectors, 1960-1998

\begin{tabular}{|c|c|c|c|c|c|c|c|c|c|c|c|c|}
\hline & \multicolumn{3}{|c|}{ United Kingdom } & \multicolumn{3}{|c|}{ West Germany } & \multicolumn{3}{|c|}{ France } & \multicolumn{3}{|c|}{ U.S. } \\
\hline & $\operatorname{Agr}$. & Ind. & Srv. & $\operatorname{Agr}$ & Ind. & Srv. & $\operatorname{Agr}$. & Ind. & Srv. & Agr. & Ind. & Srv. \\
\hline 1960 & 4.7 & 46.1 & 49.2 & 13.9 & 46.0 & 40.1 & 23.2 & 37.5 & 39.3 & 8.5 & 33.4 & 58.1 \\
\hline 1979 & 2.7 & 37.3 & 60.0 & 5.2 & 42.9 & 51.9 & 8.8 & 35.4 & 55.8 & 3.6 & 30.2 & 66.2 \\
\hline 1998 & 1.7 & 26.1 & 72.2 & 2.8 & 33.6 & 63.6 & 4.2 & 23.9 & 71.9 & 2.6 & 22.2 & 75.2 \\
\hline
\end{tabular}

Notes: Entries represent civilian employment shares in agriculture (agr.), industry (ind.) and services (srv.). Source: US BLS (2000b). 
Appendix Table 4: Changes in Skill Characteristics of UK Workers, 1975-96

\begin{tabular}{|c|c|c|c|c|}
\hline \multirow[b]{3}{*}{ Period } & \multicolumn{3}{|c|}{ Percent with } & \multirow[b]{2}{*}{ Percent } \\
\hline & Mean Years & Higher Vocational & Percent with & \\
\hline & Schooling & Qualifications & University Degree & Male \\
\hline $1975-77$ & 10.8 & 6.5 & $4 \cdot 6$ & 59.5 \\
\hline $1978-80$ & 11.1 & 7.6 & 5.8 & 57.7 \\
\hline $1981-83$ & 11.2 & 8.5 & 6.6 & 56.8 \\
\hline $1984-86$ & $11 \cdot 6$ & 11.5 & 9.0 & 54.8 \\
\hline $1987-89$ & $11 \cdot 8$ & 13.1 & 9.9 & 53.0 \\
\hline $1990-92$ & 12.0 & 13.7 & 10.6 & $51 \cdot 1$ \\
\hline $1993-96$ & 12.4 & 14.8 & 13.3 & 49.8 \\
\hline
\end{tabular}

Notes: Based on unweighted tabulations of individuals who were employed during the survey week in the 1975-96 General Household Surveys. Mean years of schooling is calculated following schmitt (1996). Higher qualifications include National Higher Certificate or Diploma, City and Guilds Advanced and Full Technological Certificates, qualifications obtained from Polytechnical and similar institutions, and ordinary National Certificate or Diploma. 
Appendix Table 5: Union Membership Rate Among Wage and Salary Employees in the United Kingdom and the United States, 1960-1999

United Kingdom
(1)
(2)
United States

1960

$41 \cdot 3$

$--$

30.4

1965

40.5

$--$

27.6

1970

48.2

$--$

26.4

1975

49.4

$--$

24.6

1980

52.9

$--$

22.2

1985

46.6

$--$

17.5

1990

40.0

38.1

15.3

1995

$--$

32.1

14.0

1999

- -

29.5

13.5

Notes: Column (1) is taken from Metcalf (1994, Table 4.1) and is estimated from union membership data. Column (2) is taken from Hicks (2000, Table 2) and is based on Labor Force Survey data. Column (3) is taken from Freeman (1997), updated by Farber and Western (2000), and is based on a combination of data sources. 
Appendix Table 6: Self-Employment Rates in the United Kingdom,

West Germany, and the United States, 1960-1999

\begin{tabular}{|c|c|c|c|}
\hline & & West & \\
\hline & $\begin{array}{c}\text { United Kingdom } \\
\text { (1) }\end{array}$ & $\begin{array}{c}\text { Germany } \\
\text { (2) }\end{array}$ & $\begin{array}{c}\text { United States } \\
\text { (3) }\end{array}$ \\
\hline 1960 & 7.2 & -- & -- \\
\hline 1965 & 6.7 & -- & 8.9 \\
\hline 1970 & 7.7 & 16.6 & 8.3 \\
\hline 1975 & 8.0 & 14.0 & 8.9 \\
\hline 1980 & 8.4 & 11.7 & 9.6 \\
\hline 1985 & 11.3 & 11.4 & 9.9 \\
\hline 1990 & 13.1 & 10.6 & 10.6 \\
\hline 1995 & 13.0 & 11.0 & 10.9 \\
\hline 1999 & 12.7 & 11.3 & 10.3 \\
\hline
\end{tabular}

Notes: Column (1) is derived from data in Economic Trends (Annual Supplement, 1997, Table 3.8), updated with data from the Labor Force Survey. Column (2) is derived from data in Statistisches Jahrbuch (1998, Table 6.3): the estimated self-employment count includes family workers. Column (3) is based on authors' tabulations of March Current Population Survey. 1965 entry for U.S. is based on 1967 data. 
Appendix Table 7: Fraction of Employment in Government or Public Sectors

\begin{tabular}{|c|c|c|c|c|c|}
\hline & \multicolumn{2}{|c|}{ United Kingdom } & \multirow[b]{2}{*}{ General } & \multirow[b]{2}{*}{ Government } & \multirow[b]{2}{*}{ United States } \\
\hline & & Nationalized & & & \\
\hline & Government & Industries & Germany & France & (Public sector) \\
\hline & ( 1 ) & $(2)$ & (3) & $(4)$ & ( 5 ) \\
\hline 1960 & 15.2 & 8.8 & 8.1 & -- & -- \\
\hline 1965 & 16.3 & 7.5 & -- & -- & 15.3 \\
\hline 1970 & 18.7 & 7.6 & 10.9 & -- & 15.6 \\
\hline 1975 & 21.7 & 7.3 & 13.0 & 17.4 & 17.5 \\
\hline 1980 & 21.9 & 7.1 & -- & -- & 16.2 \\
\hline 1985 & 22.7 & 4.6 & 15.5 & 22.9 & 15.0 \\
\hline 1990 & 21.3 & 2.5 & 15.1 & $22 \cdot 8$ & 15.0 \\
\hline 1995 & 19.7 & 1.4 & 15.1 & 24.8 & 14.4 \\
\hline 1999 & -- & -- & -- & -- & 14.1 \\
\hline
\end{tabular}

Notes: Data in columns (1) and (2) are derived from data in Economic Trends (Annual Supplement, 1997, Table 3.8). Government includes general government and National Health Service Trusts (after 1991). Nationalized industries include the Post office. Data in columns (3) and (4) are taken from OECD Historical Statistics, 1960-1994, Table 2.13. Data in column (5) are based on authors' tabulations of March Current population Survey, and include employees who report that they work for the government. 
Figure 1: Trends in Real GDP per Capita Relative to 1979 for United Kingdom, West Germany and France, and the United States

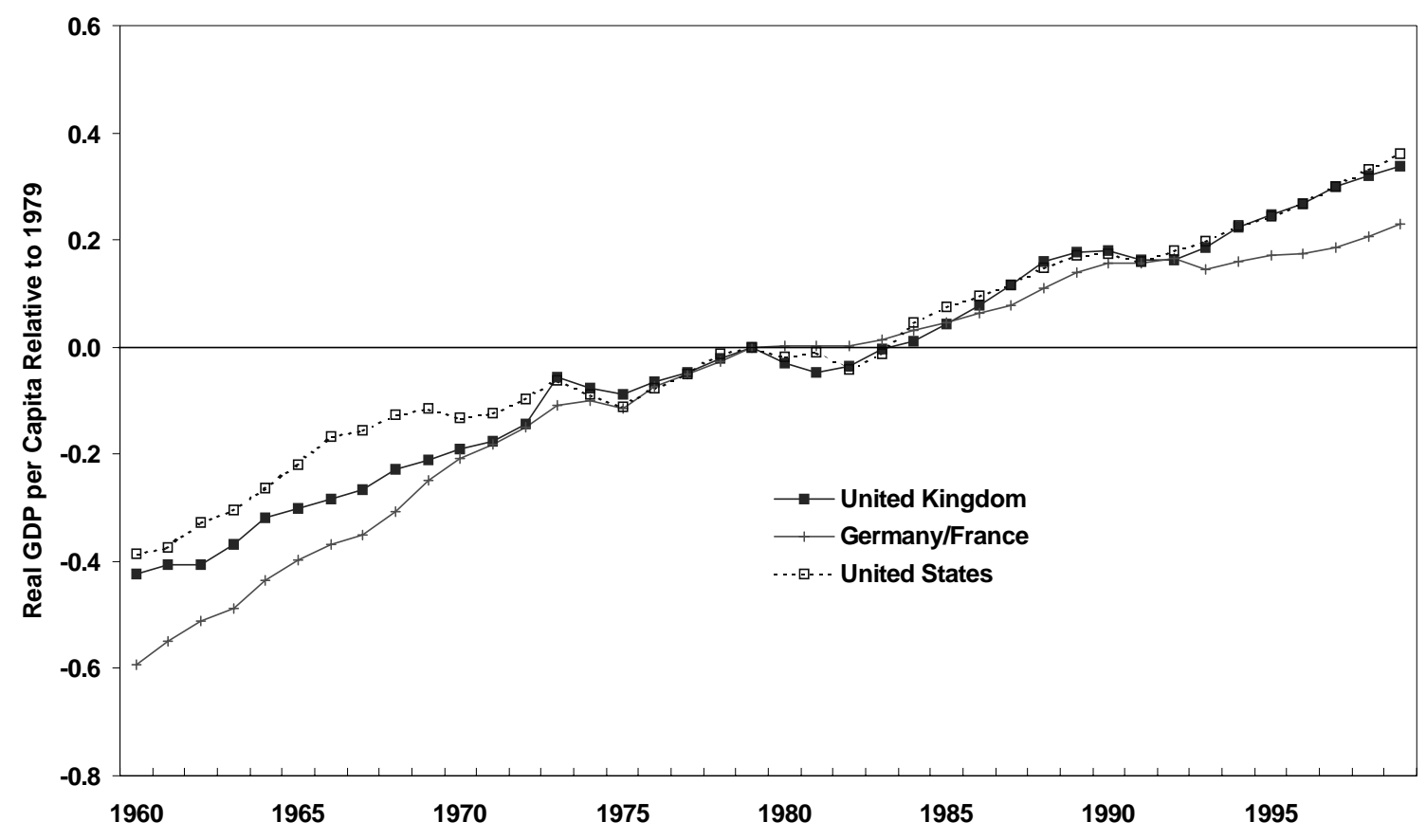


Figure 2: Trends in Real GDP per Worker and Employment per Capita Relative to 1979 for United Kingdom, West Germany and France, and the United States

A. Real GDP per Worker

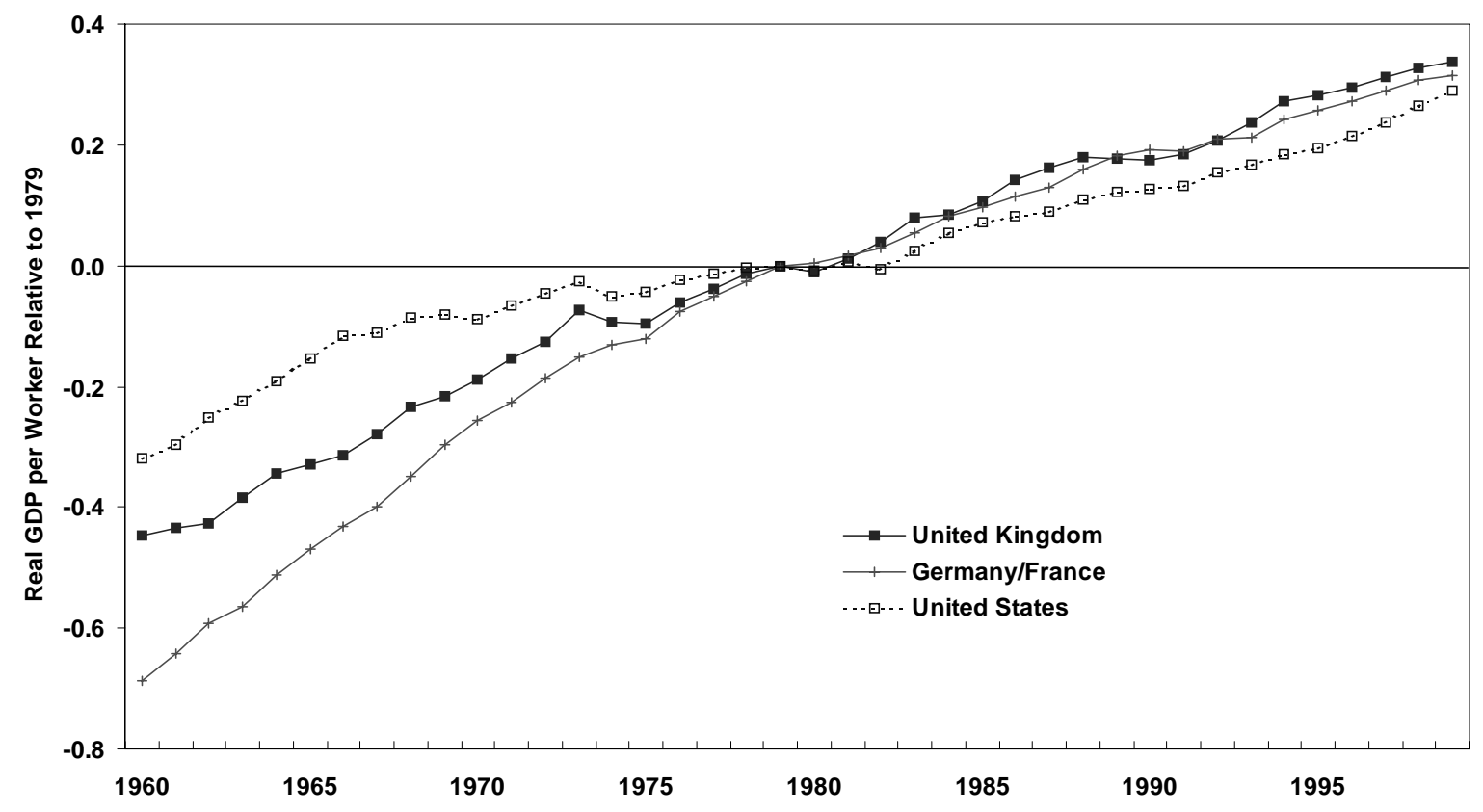

B. Employment per Working Age Person

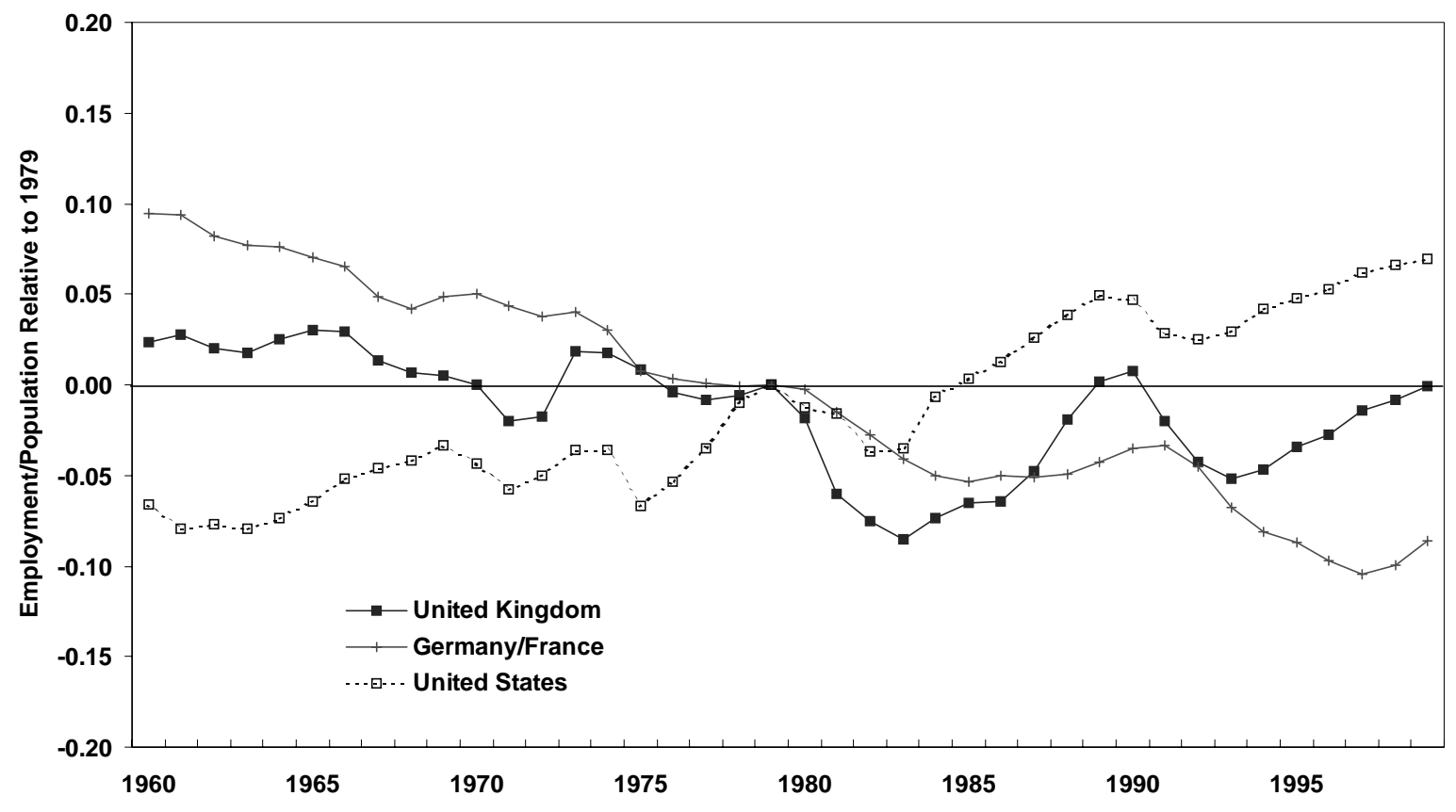


Figure 3: Trends in Real GDP per Hour and Hours per Capita Relative to 1979 for United Kingdom, West Germany and France, and the United States

A. Real GDP per Hour

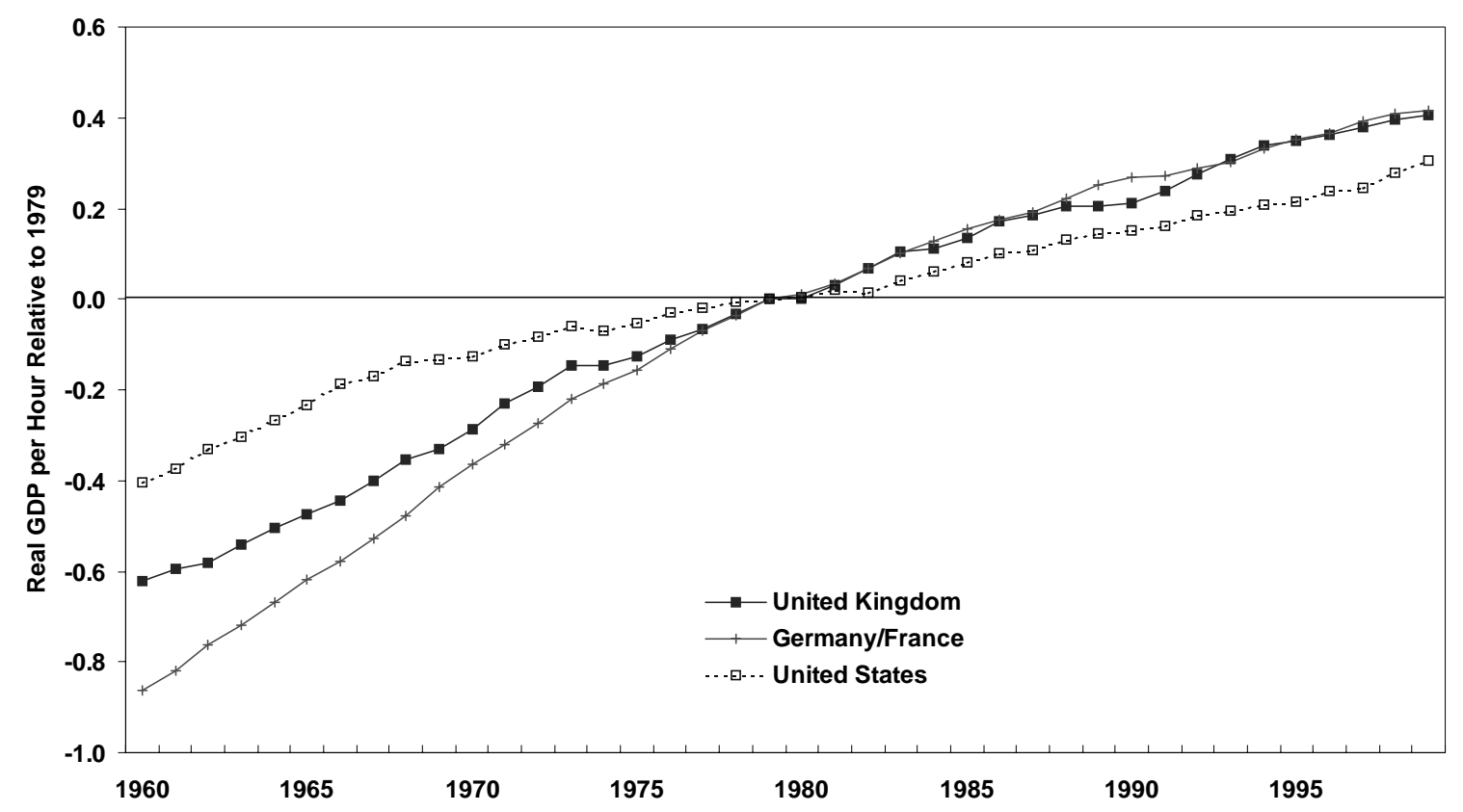

B. Hours per Working Age Person

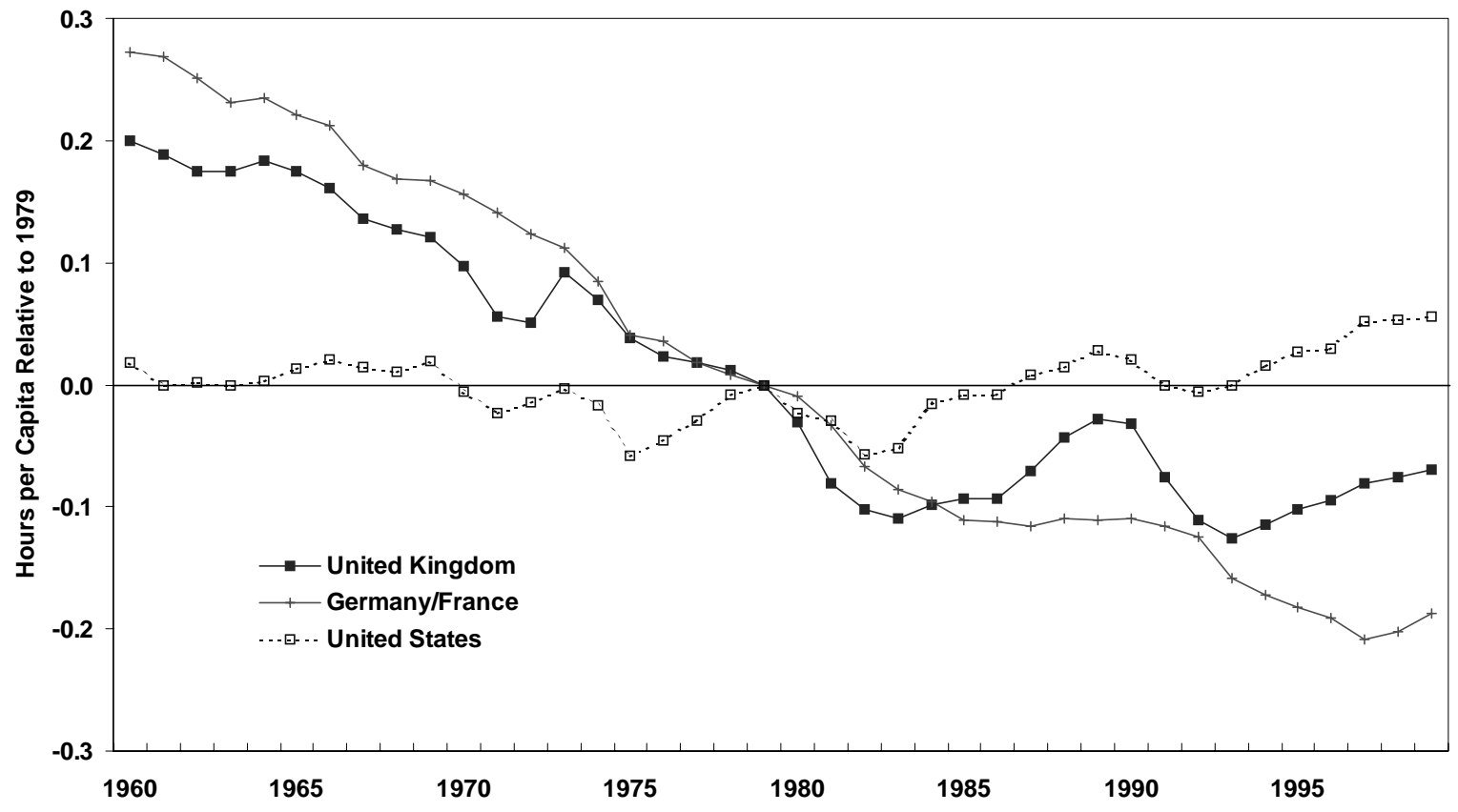


Figure 4: Trends in Capital per Worker In the United Kingdom, West Germany, France, and the United States

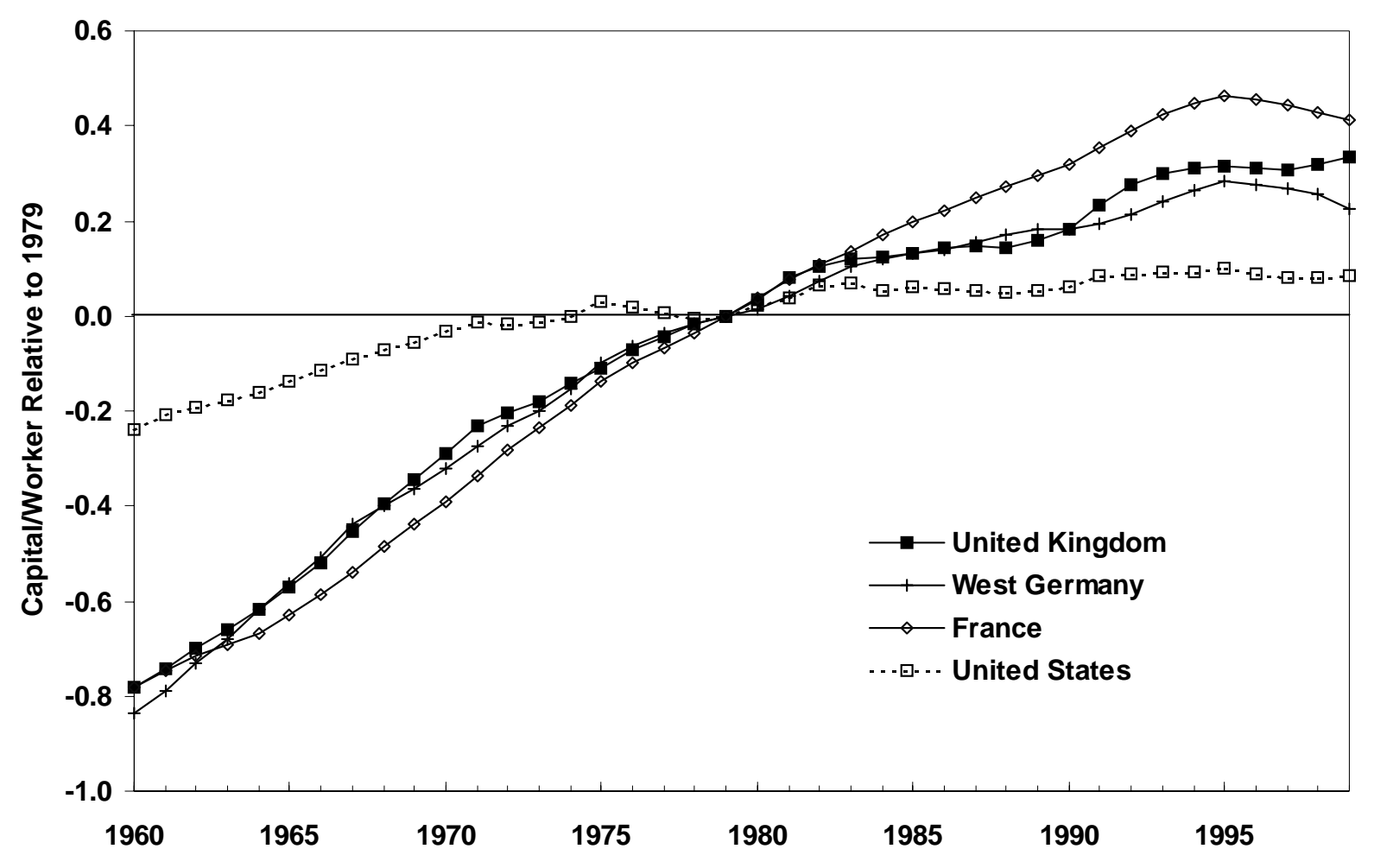

